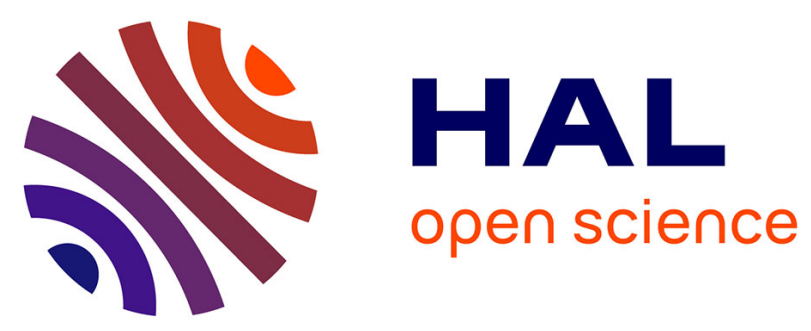

\title{
KINEMATICS OF DUCTILE SHEARING FROM OUTCROP TO CRUSTAL SCALE IN THE MONTE ROSA NAPPE, WESTERN ALPS
}

Robin Lacassin

\section{- To cite this version:}

Robin Lacassin. KINEMATICS OF DUCTILE SHEARING FROM OUTCROP TO CRUSTAL SCALE IN THE MONTE ROSA NAPPE, WESTERN ALPS. Tectonics, 1987, 6 (1), pp.69 - 88. 10.1029/TC006i001p00069 . insu-01887072

\section{HAL Id: insu-01887072 https://hal-insu.archives-ouvertes.fr/insu-01887072}

Submitted on 3 Oct 2018

HAL is a multi-disciplinary open access archive for the deposit and dissemination of scientific research documents, whether they are published or not. The documents may come from teaching and research institutions in France or abroad, or from public or private research centers.
L'archive ouverte pluridisciplinaire HAL, est destinée au dépôt et à la diffusion de documents scientifiques de niveau recherche, publiés ou non, émanant des établissements d'enseignement et de recherche français ou étrangers, des laboratoires publics ou privés. 
TECTONICS, VOL. 6, NO. 1, PAGES 69-88, FEBRUARY 1987

KINEMATICS OF DUCTILE SHEARING

FROM OUTCROP TO CRUSTAL SCALE

IN THE MONTE ROSA NAPPE,

WESTERN ALPS

Robin Lacassin 1

Laboratoire de Géologie Structurale, Centre National de la Recherche

Scientifique, Montpellier, France

Abstract. Significant ductile deformation has produced widespread mylonitic structures in the basement orthogneisses and the Mesozoic cover quartzites and marbles of the Monte Rosa nappe, in the inner part of the Western Alps. We summarize here the results of a detailed microstructural study at several scales of observation in the Northern part of the nappe and discuss the kinematic significance and compatibility of such results. Most of the observed deformations can be accounted for by progressive WNW-vergent shearing during and after the late Eocene, within a ductile shear zone of crustal scale. The displacement of the hanging wall may have been in excess of several tens of kilometers. However, some ESE-vergent shear criteria cannot be reconciled with this general picture and suggest that local backthrusting occurred later near the toe of the Monte Rosa nappe.

\footnotetext{
INow at Laboratoire de Tectonique, Mécanique de la Lithosphère, Centre National de la Recherche Scientifique, Institut de Physique du Globe de Paris, France.

Copyright 1987

by the American Geophysical Union.

Paper number 6T0604. 0278-7407/87/006T-0604\$10.00
}

\section{INTRODUCTION}

One important problem in mountain belts is the relationship between numerous field observations on the geometry of deformations at the outcrop scale, and plate-scale kinematic models. The simplicity of the latter often appears to conflict with the apparent complexity of smal1-scale deformations. We show here that detailed analyses of ductile deformations in part of the internal Alps an a synthesis of such observations at a regional scale $(100 \mathrm{~km})$ are compatible with a simple, coherent model.

The Monte Rosa nappe, northernmost internal crystalline massif of the Western Alps, situated on the Swiss-Italian border (Figure 1), has been famous since Argand's cross sections. Following Argand's general interpretation of the Monte Rosa nappe as a large recumbent fold [Argand, 1911], subsequent tectonic studies, e.g., Homewood et al. [1980] and review by Müller [1982], were mostly concerned with the description of several phases of folding and of the complex geometric structures thought to result from fold interference patterns. Speculative maps of fold axial plane traces [Klein, 1978; Milnes et al., 1981] have been extrapolated over large regions following the concept of structural cylindricity [Argand, 1911]. The inferred folding phases have been related to "backfolding" 


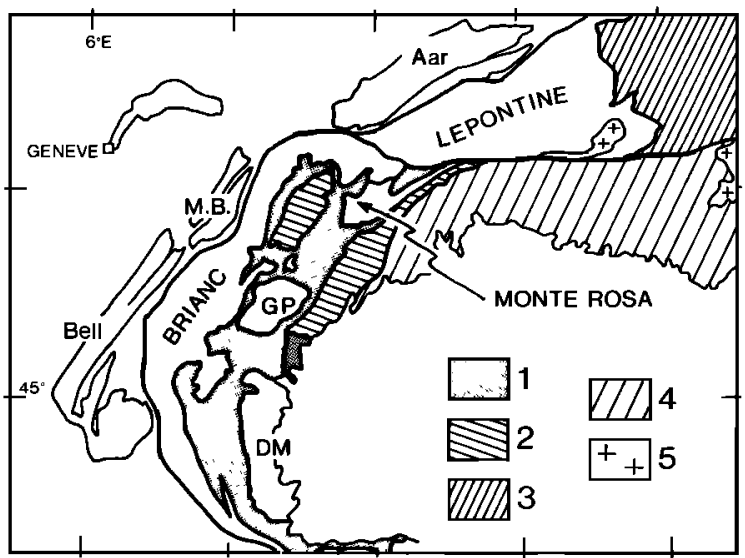

Fig. 1. Western and Central Alps. Units related to south Alpine continent are dashed: (2) Sesia and Dent Blanche nappe, (3) Austroalpine nappes, (4) South Alpine units; shaded areas (1) represent ophiolites and oceanic sediments ("schistes lustrés"). Posttectonic sediments of Po plain and European continental crust are in white. The latter may be divided into: internal crystalline massifs (Dora maira, Gran Paradiso, Monte Rosa), Briançonnais and Lepontine nappes, external zones with Pelvoux, Belledonne, Mont Blanc and Aar crystalline massifs. Crosses (5) show syntectonic to posttectonic intrusives.

during a complex "late" tectonic history following earlier stacking of Northwest vergent thrust nappes. Despite this apparent complexity, however, widespread ductile deformation in the deeper parts of the Northwestern internal Alps appears to be simple and coherent, and stretching lineations, which remain constant in direction or show traceable progressive variations (Figures 1 and 2 ), probably represent good markers of tectonic movements, as in various shear zones [Ramsay and Graham, 1970; Escher and Watterson, 1974], or in adjacent parts of the Alps and other mountain belts [Nicolas and Boudier, 1975; Mattauer, 1975; Laurent and Etchecopar, 1976; Malavieille and Etchecopar, 1981; Mattauer et al., 1983]

In this paper we first analyze this ductile deformation, with particular emphasis on microstructures, mechanisms and regime. Then we discuss the regional compatibility of the different observations and attempt to relate such observations to large tectonic movements (thrusting, crustal shearing) and a plate scale interpretation of the Western Alps.

\section{GEOLOGICAL SETTING}

The Pennine nappes described by Argand [1911] throughout the Swiss Alps are large recumbent folds formed of basement cores separated by thin layers of mostly mesozoic sedimentary rocks. The basement, of presumed Hercynian age, is made of micaschists, paragneisses, and amphibolites intruded by late Paleozoic granites. The Permo-Carboniferous to Mesozoic sequence overlying this basement comprises, from bottom to top, volcanoclastic sediments, schists, conglomerates and quartzites of Permian to Triassic age, and marbles, calcschists and "schistes lustrés" of Jurassic to Cretaceous age, all of them deposited on the passive European continental margin. Ophiolites and oceanic sedimentary rocks have been thrusted onto these units.

The area we studied is located at the northern border of the Monte Rosa nappe, south of a late SSE vergent fold, the Mischabel "backfold", which affects the Grand St. Bernard nappe (Figures 3 and 4 ). Deformations were mostly analyzed in four of the main structural units outcropping in this area:

The reworked Hercynian basement [Bearth, 1952] in part of the MR nappe, and the Portjengrat unit. These are separated by the Furg zone, a complex melange of paragneissic rocks including a lot of amphibolite and eclogite boudins [Wetze1, 1972].

The Gornergrat zone, which is formed of mesozoic rocks (quartzites, marbles...) and constitutes the detached cover of the Monte Rosa nappe [Güller, 1947; Bearth, 1976].

Part of the Zermatt Saas-Fee ophiolite thrust sheet (schistes lustrés, serpentinites, gabbros...), [Bearth, 1967 ] .

Two major metamorphic events affect these units: (1) an early alpine highpressure metamorphism and (2) a retromorphic event under greenschist conditions. The first event is well documented in the ophiolites [Kiénast, 1973; Ernst and Dal Piaz, 1978; Oberhänsli, 1980; Carpenter, 1981] and in the Furg zone [Wetze1, 1972]. In the Monte Rosa nappe itself, this event may be separated into two subevents [Chopin and Monié, 1984; Monié, 1984]: (1) an earlier eclogitic one (around 15 kbar) described in the southern part of the MR nappe and dated at about $110 \mathrm{Ma}$ [Chopin and Monié, 1984] and (2) a later one of lower 


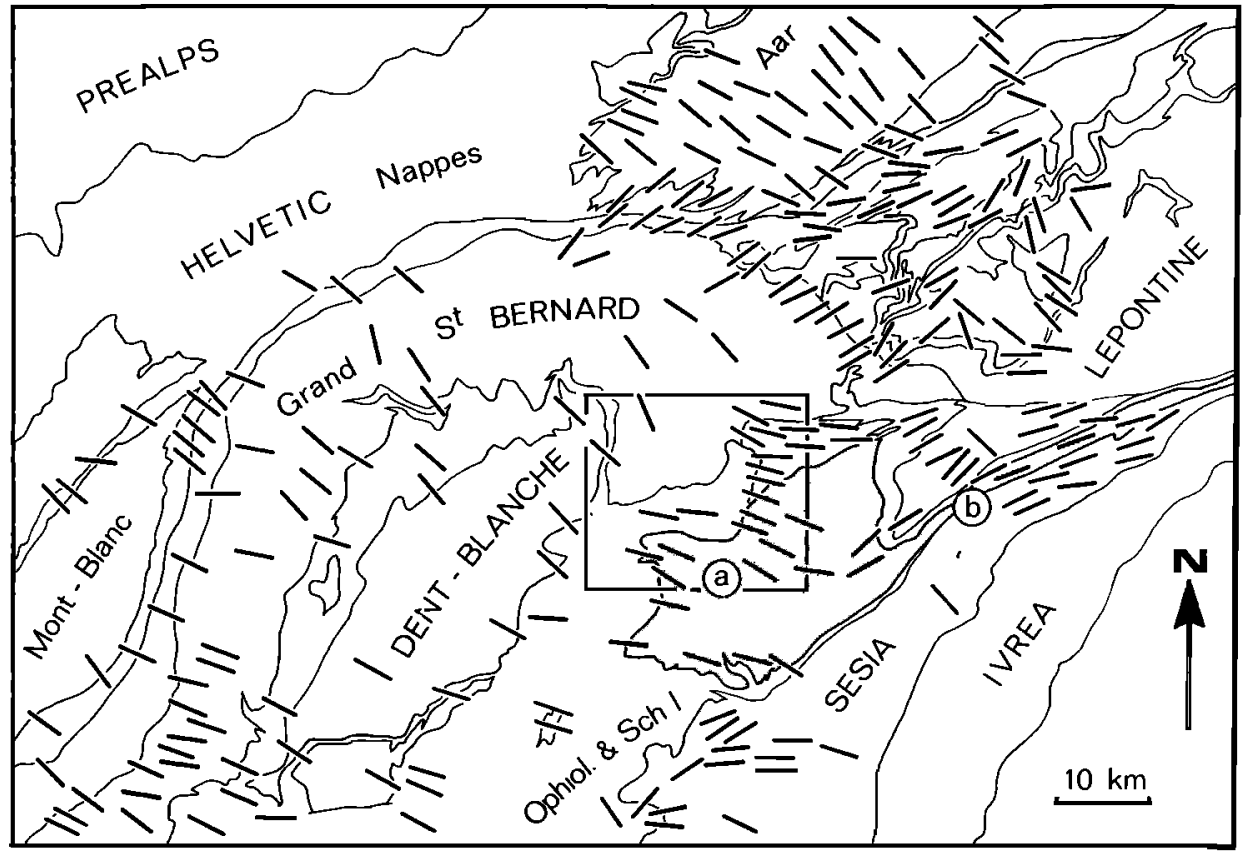

Fig. 2. Structural sketch map of Northwestern Alps; Monte Rosa is shaded: (a) studied area, (b) Eastern steep zone. Stretching lineations (bold dashes) from Reinhardt [1966], Malavieille et al. [1984], Steck [1984], and this paper. Boxed area refers to Figure 3 .

pressure (garnet-glaucophane facies, 78 kbar) dated between 70 and $60 \mathrm{Ma}$. Both early high-pressure assemblages are partly retromorphosed during the second metamorphic event, present throughout the Pennine zone [Ernst, 1973]. This latter event is dated at about $40 \mathrm{Ma}$ [Hunziker, 1970; Monié, 1984], hence earlier than the Lepontine high temperature climax (30 to $15 \mathrm{Ma}$ ) [Frey et al., 1974].

\section{GENERAL CHARACTER OF DEFORMATIONS}

In all rocks of the area, outstanding ductile deformation produced a strong foliation parallel to the stratification $\left(\mathrm{S}_{0}\right)$, and prominent stretching lineations. Only one foliation $\left(S_{1}\right)$ is generally observed in orthogneissic rocks, despite local occurrences of crosscutting mylonitic shear zones. In the well-layered sedimentary rocks, on the other hand, composite fabrics may be observed at places where $S_{1}$ is refolded and a new axial plane foliation $\left(S_{2}\right)$ appears.

The regional foliation $\left(\mathrm{S}_{1}\right)$ plunges $10^{\circ}$ to $40^{\circ}$ to the north on the average. Toward the SE it is refolded in the Vanzone antiform [Laduron, 1976] and becomes vertical in the so-called root zone, between Villadossola and Locarno (area b, Figure 3).

Depending on rock types, stretching lineations are defined by different markers: in gneisses, elongated feldspar porphyroclasts with recrystallization tails (Figure 5a), and quartz or mica ribbons which form elliptical spots on the foliation; elongated quartz pebbles in conglomeratic quartzites (Figure $5 b$ ); elongated and stretched dolomitic porphyroclasts or layers in marbles (Figures 5c and 5d); stretched garnets with recrystallization tails in mica schists or calc-schists.

Synmetamorphic recrystallizations are parallel to stretching and marked by elongated grains of recrystallized quartz, feldspar, or calcite and the alignment of mica plates (phengite, biotite, and sometimes chlorite).

Detailed mapping [Lacassin, 1984] of the lineations at different scales indicates that they trend between $\mathrm{N} 70^{\circ} \mathrm{E}$ and $\mathrm{N} 140^{\circ} \mathrm{E}$ with a strong maximum around $\mathrm{N} 110^{\circ} \mathrm{E}$ (Figures 6 and 7). Their pitch in the foliation is generally close to $90^{\circ}$. Despite some variations which are progressive and may be related to heterogeneous deformation in anastomosed 


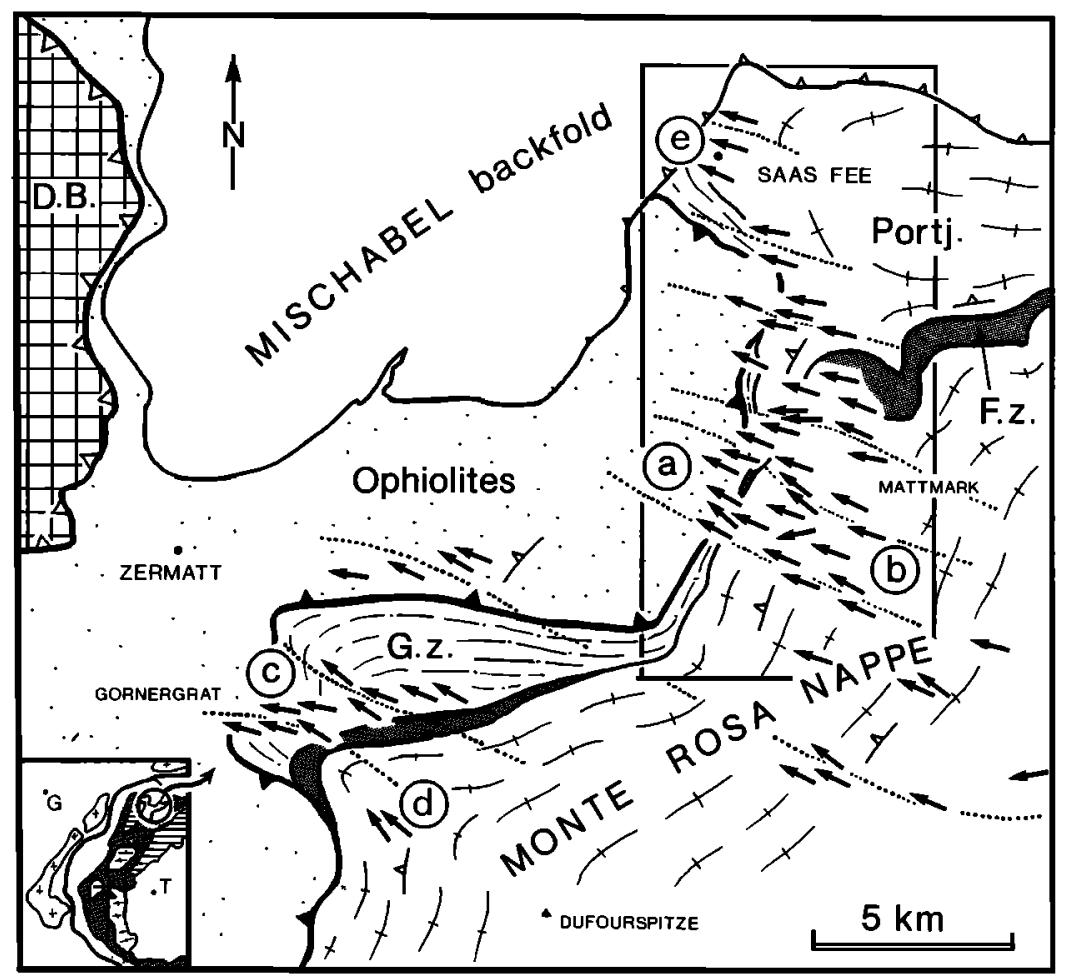

Fig. 3. Regional lineation map of Northern Monte Rosa nappe. Arrows represent stretching lineations with plunge, dotted lines outline lineation trend. (a) Kilometer-scale sheath fold in Gornergrat zone near Mattmark [Lacassin and Mattauer, 1985]; (b) and (d) mylonites and shear zones in granites [Lacassin, 1983a] at Mattmark and near Monte Rosa Hütte, respectively; (c) westward shearing in cover rocks at Gornergrat [Lacassin, 1983b]; (e) eastward shear criteria in orthogneisses near Saas Fee. Boxed area refers to Figure 7 .

shear zones of various scales (Figures 6 and Lacassin [1983a]), their directions are regionally coherent (Figure 3 ) and there are no significant variations between the different units.

Foliations and lineations were assumed to be parallel to $X Y$ and $X$, respectively ( $\mathrm{X} \geq \mathrm{Y} \geq \mathrm{Z}$, strain ellipsoid axes) [Flinn, 1965; Nicolas and Poirier, 1976].

\section{DEFORMATION OF BASEMENT ROCKS AND} PROGRESSIVE MYLONITIZATION OF GRANITES

Basement units are mostly formed of granitic rocks strongly affected by alpine tectonics. Orthogneisses, in general, record most clearly structures and deformation mechanisms. Due to the lack of prealpine deformation and of initial anisotropy or heterogeneity, deformation of the granites is less perturbed, and simpler than in the sediments which show several "phases" of folding.

\section{Strain Geometry}

The granites are interleaved in polymetamorphic paragneissic rocks and form large orthogneiss masses which contain pods of relatively undeformed

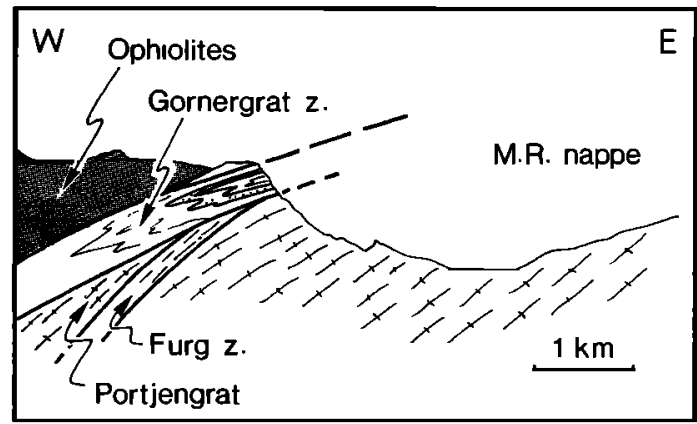

Fig. 4. Schematic cross section of studied area; approximately $a-b$ on Figure 3 . 
granites some $100 \mathrm{~m}$ wide. Shear zones limit or cut these pods of granites [Lacassin, 1983a]; they are particularly clear, for instance, along the Western Mattmark lake shore (Figures 3b, 6, and 7) or near the Monte Rosa Hütte (Figure 3d) in the upper Zermatt valley.

These shear zones form anastomosing nets of mylonitic bands $(50 \mathrm{~cm}$ to $5 \mathrm{~m}$ thick) each with gently deformed gneiss at the rims passing to highly deformed, finegrained mylonites toward the center (Figure $8 \mathrm{a}$ and $\mathrm{b}$ ). The geometry of anastomosing shear zones observed near Mattmark is schematized in Figure 9 [Lacassin, 1983a]. One may note the absence of conjugate shear zones and the prominent WNW-directed sense of movement, parallel to the lineation, despite local components toward the $\mathrm{N}$ or $\mathrm{S}$.

The gneisses surrounding the granite pods are characterized by homogeneous strain with local occurrence of anastomosing mylonitic bands separating "fishlike" pods of foliated gneisses, about $100 \mathrm{~m}$ wide. Such bands are generally less than $1 \mathrm{~m}$ thick and either parallel to or crosscutting the gneissic foliation. In the latter case they may dip as much as $10^{\circ}$ more steeply to the West than the gneissic foliation.

\section{Deformation Mechanisms}

The quartz forms very long polycrystalline ribbons, particularly in mylonites. Grains are equant $(50 \mu \mathrm{m})$ or gently elongated. They show few internal deformation figures and have sutured or straight boundaries. Such microstructures are therefore typical of plasticity and dynamic recrystallization [e.g., White, 1976]. In some mylonitic bands, ribbons of elongated grains with deformation bands and subgrains oblique to the foliation reflect the imprint of late low temperature $\left(300^{\circ}\right.$ to $\left.350^{\circ} \mathrm{C}\right)$ strain increments [Brunel, 1980].

The quartz c axis fabrics (Figure 10) are well defined and show asymmetric girdles characteristic of noncoaxial deformation [e.g., Laurent and Etchecopar, 1976; Bouchez and Pêcher, 1976; Burg and Laurent, 1978]. The several maxima in the girdles (Figure 10) suggest activation of at least two slip systems (basal " $a$," and prismatic "a," [Bouchez and Pêcher, 1976; Etchecopar, 1984]) and hence temperature conditions of about $500^{\circ} \mathrm{C}$. However, in some mylonitic bands, maxima close to $\mathrm{Z}$ only, characteristic of basal slip, probably reflect lower temperature conditions (Figures $10 \mathrm{~d}$ and $10 \mathrm{e}$ ).

The feldspars are deformed and recrystallized. In gently deformed gneisses, porphyroclasts of orthoclase or microcline ( $5 \mathrm{~mm}$ to $2 \mathrm{~cm}$ large), often perthitic, have a monocrystalline core surrounded by a mantle of small recrystallized grains (albite, oligoclase, and quartz) [Higgins, 1971; White, 1976]. Recrystallization has probably been induced by plastic deformation at the core rim or in shear zones which affect the core. In mylonites, porphyroclasts are reduced in size ( 1 to $5 \mathrm{~mm}$ ) and drastically recrystallized (Figure 11, part A). The fine grained mantle is stretched in elongated tails which may include pressure shadow crystallizations. In shear zones with clear shear senses, feldspar deformation patterns illustrate two major, reliable shear criteria (Figure 11, parts $B$ and C) [Lacassin, 1984]: (1) the porphyroclast/tail sigmoidal shape or asymmetry is synthetic of bulk shear sense, and (2) slip on most fractures within feldspar cores is antithetic of bulk shear sense (Figure 11, part B). These observations concur with the conclusions of Lagarde [1978], Malavieille et al. [1982], and Simpson and Schmid [1983].

In mylonites, the finely layered matrix is formed of often elongated or irregular small grains $(10 \mu \mathrm{m})$ of feldspar (albite, oligoclase), quartz, and mica (phengite). These characters and the fact that quartz c axis fabrics are $i 11$ defined suggest the occurrence of grain boundary sliding [Schmid, 1983].

\section{Deformation Regime}

Most gneisses and mylonites of the area are LS tectonites, which suggests that finite strain was close to plane strain. More rarely, samples have planar fabrics which might be due either to the existence of a flattening component (i.e., in outcrops where no clear lineation is observed) or to the lack of stretching markers (i.e., in very fine grained, highly deformed mylonites).

From sample to outcrop scale, the deformation regimes appear everywhere to be noncoaxial, given the deformation patterns of feldspars porphyroclasts in sections parallel to L (Figures $8 \mathrm{c}$ and $8 \mathrm{~d}$ ). In the Monte Rosa nappe, all 


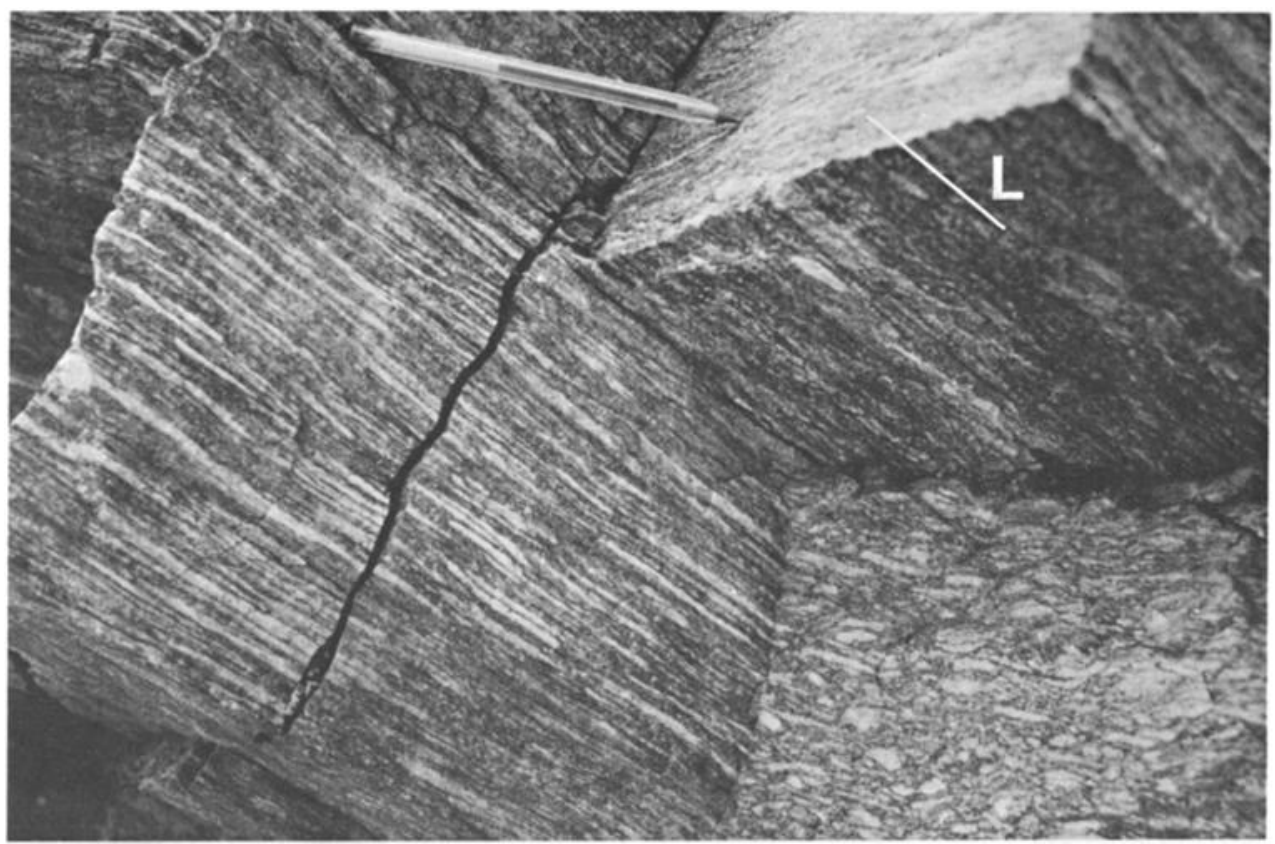

Fig. 5a.

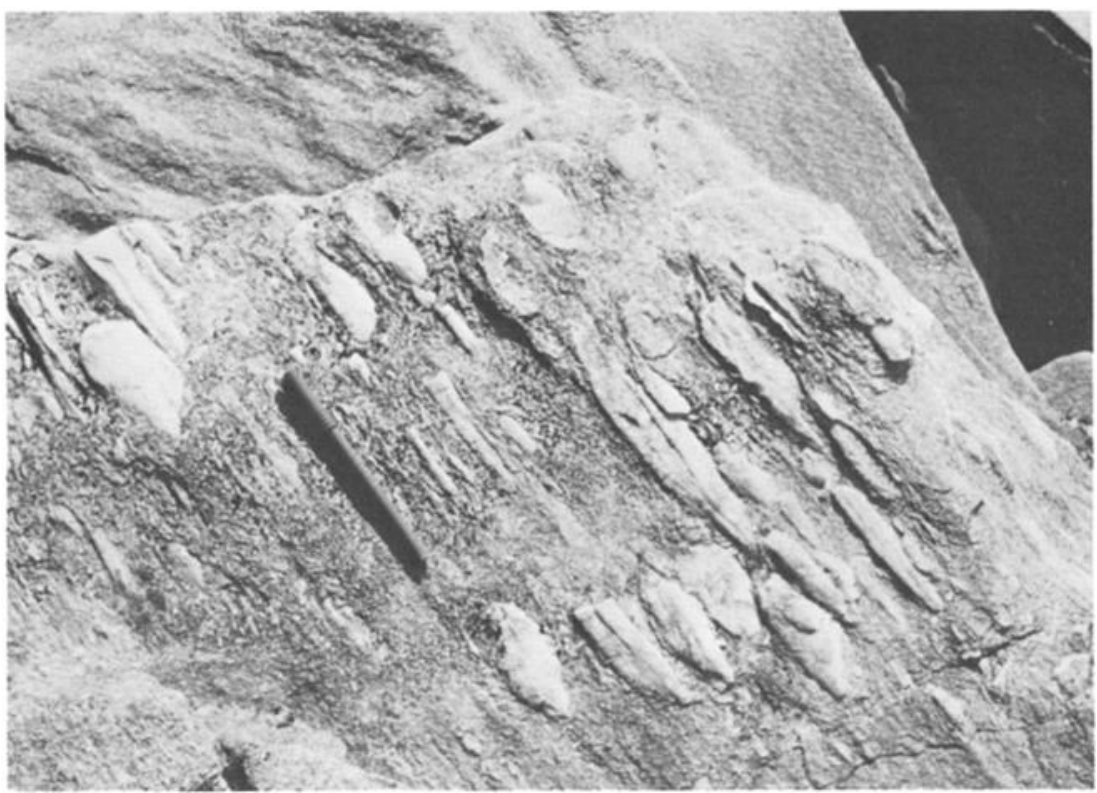

Fig. 5b.

Fig. 5. Characters of stretching in different rocks: (a) 3-D fabric in gneiss with outstanding LS fabric (near Saas Fee, Portjengrat unit); (b) elongation of quartz pebbles in conglomeratic quartzites at Gornergrat; (c) and (d) Boudinage in marbles, at Gornergrat and Mattmark, respectively; note clockwise rotation of fragments displaced by small shear zones (d), antithetic of the bulk shear sense. 


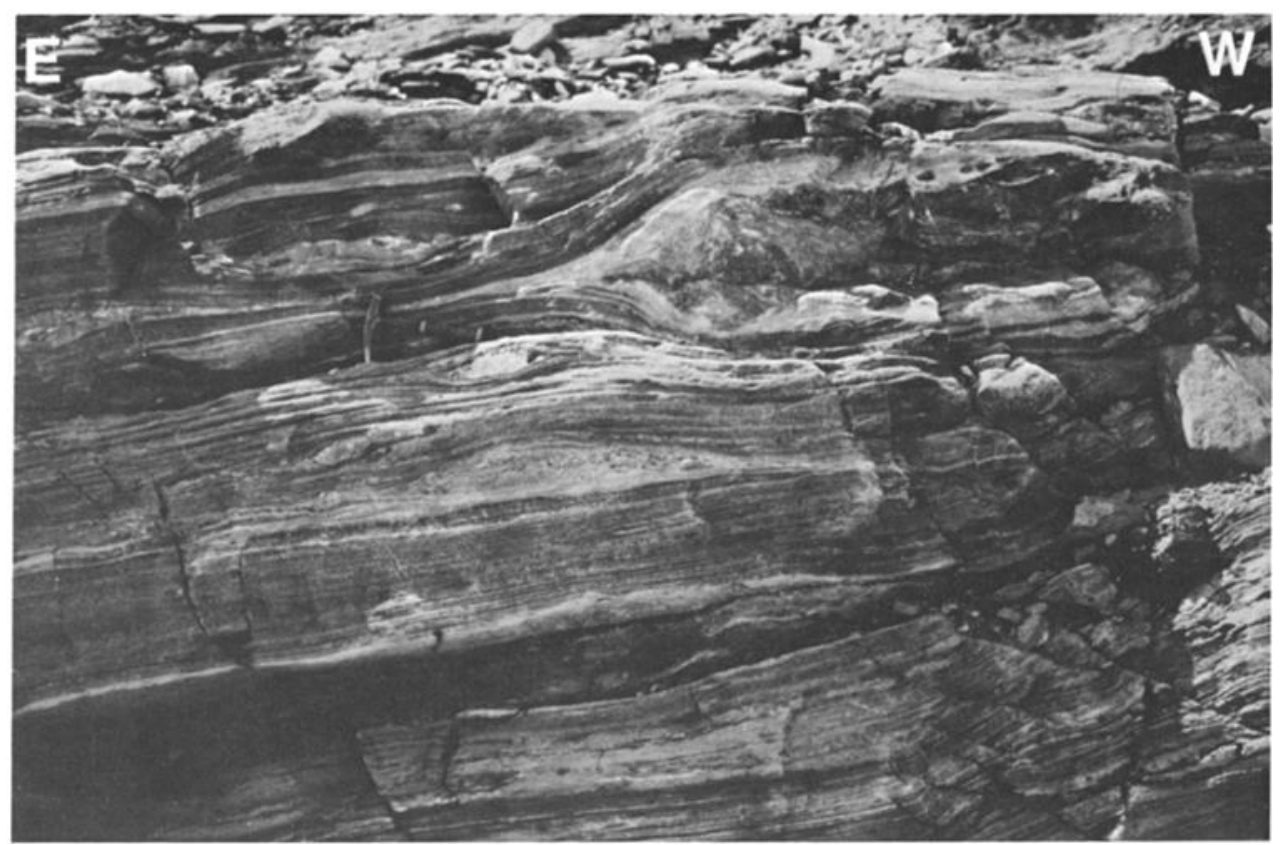

Fig. 5c.

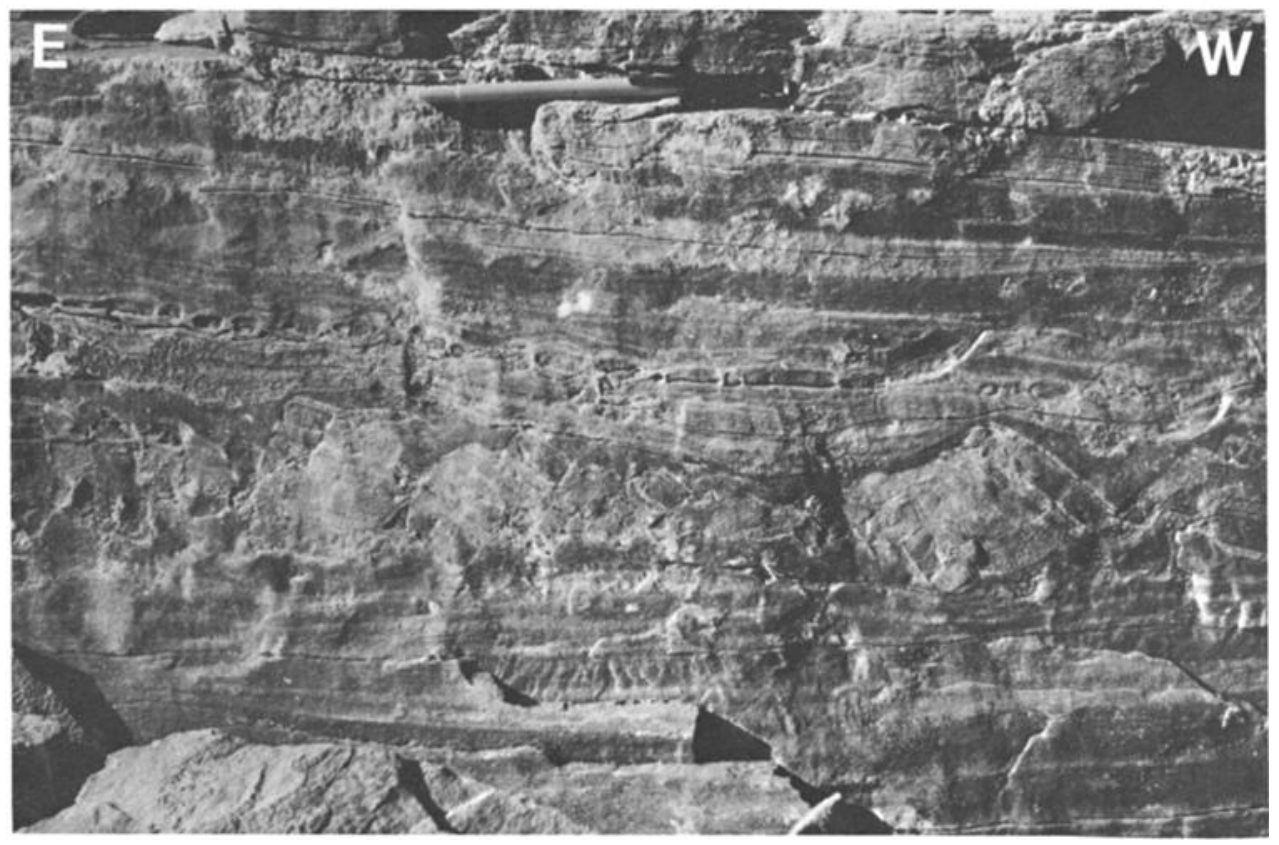

Fig. 5d. 


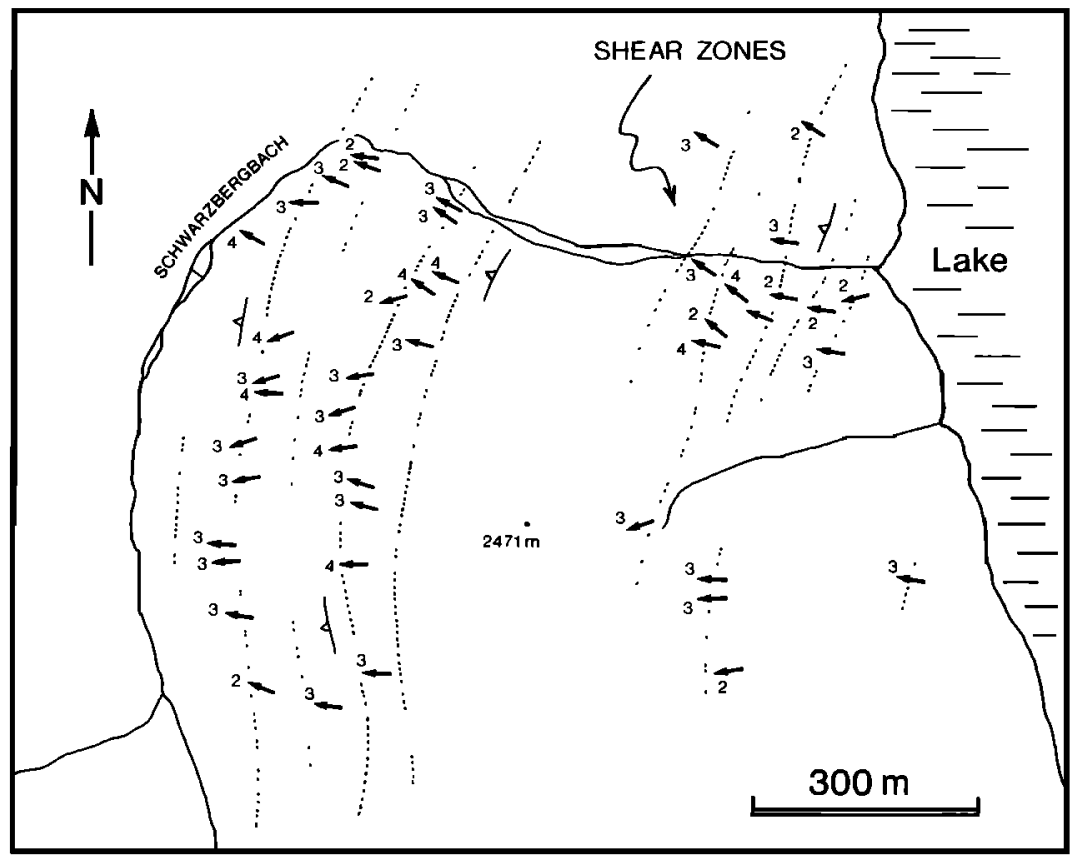

Fig. 6. Detailed structural map of orthogneiss outcrops (Western shore of Mattmark lake). Arrows represent stretching lineations with plunge (in degrees $\times 10$ ); dotted lines represent foliation direction trajectories. Curved arrow points to area of anastomosed shear zones described in Lacassin [1983a].

observed shear senses are compatible with relative movements of hanging walls. In the Portjengrat unit, however, some outstanding shear criteria (Figure 8d) in the Saas Fee orthogneisses (Figure 3e) cannot be reconciled with such a WNW vergence, although both the deformation style and the orientation of the lineation are the same as in the Monte Rosa nappe.

The lack of strain markers in basement rocks allows only for qualitative estimates of the amount of strain: (1) In shear zones the rough parallelism between mylonitic foliation and shear zone rims (the angle $\Theta$ between $S_{1}$ and the shear plane is less than $5^{\circ}$ ) implies minimum shear strain and $X / Z$ ratio close to 10 and 100 , respectively, if the strain regime is assumed to be simple shear [Ramsay, 1980]. (2) The fact that the textures of most gneissic rocks are comparable to those of rocks in shear zone regions where $\Theta$ is about $15^{\circ}$ suggests average shear strain and $X / Z$ ratio of 3.5 and 15 , respectively.

\section{Evolution of Deformation}

Several arguments are consistent with a progressive evolution of deformation under decreasing $\mathrm{P} / \mathrm{T}$ conditions:

1. In the mylonitic bands the generally deformed metamorphic minerals (phengite, chlorite, and stretched garnets) are often more retromorphic than in the surrounding gneisses (biotite and phengite sometimes high-pressure, \pm garnet).

2. In some shear zones a central ultramylonitic layer cuts the outer shear zone foliation at an angle. This is also true of some mylonitic bands which cut the gneissic foliation.

3. Quartz microstructures and $c$ axis fabrics are of relatively high temperature $\left(500^{\circ} \mathrm{C}\right)$ in orthogneisses but of lower temperature $\left(350^{\circ} \mathrm{C}\right)$ in some mylonite zones.

4. Rare late brittle movements in central parts of shear zones are sometimes marked by thin ( $1 \mathrm{~mm}$ ) pseudotachylite layers [Sibson, 1977] or cataclasis.

These characteristics thus support an interpretation in which shear zones form during retromorphosis until the ductilebrittle transition is reached. Although it is not possible to establish that deformation was progressive from incipient gneissification to late slip on 


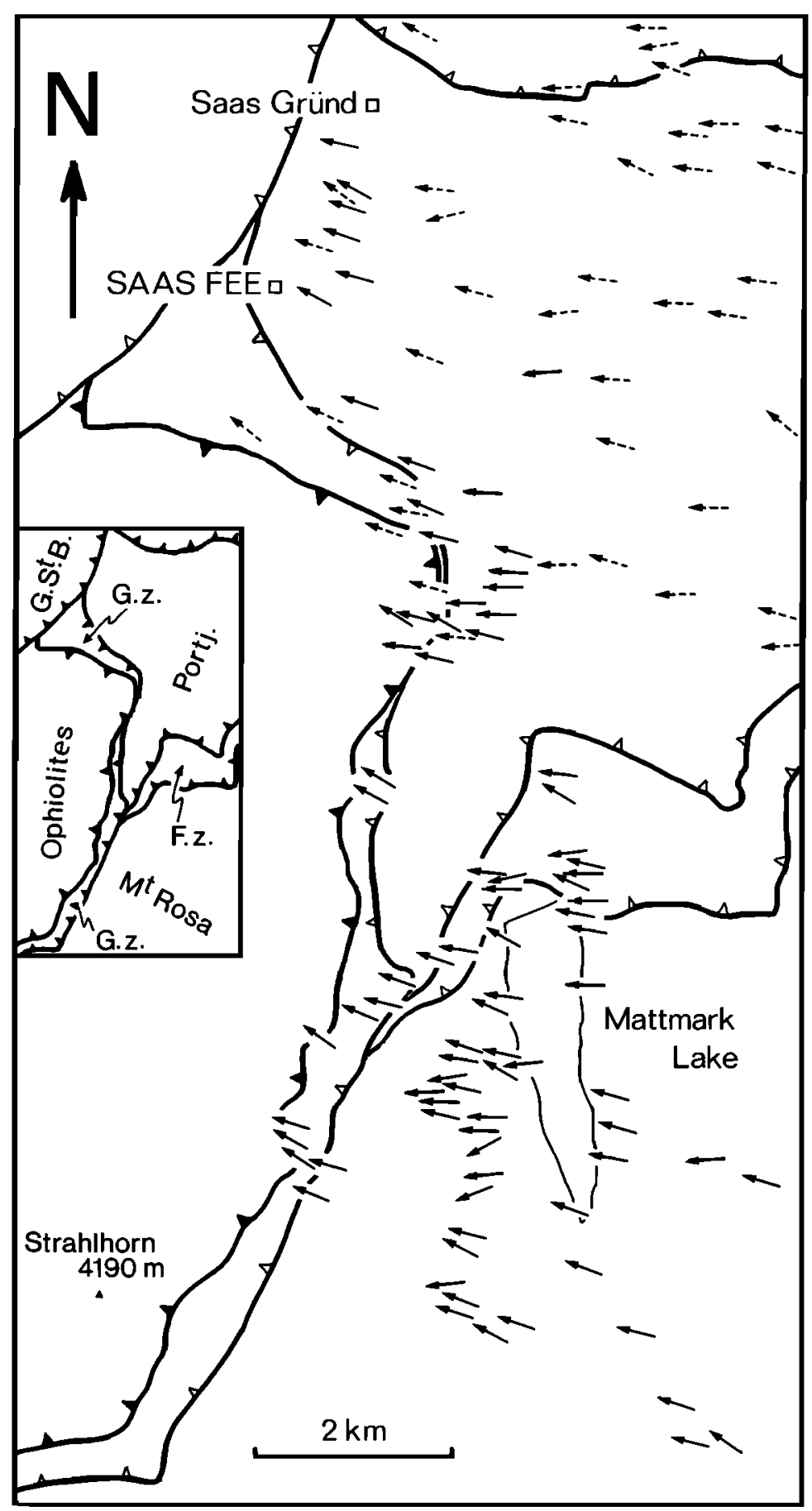

Fig. 7. Detailed lineation map of upper Saas valley, between Saas Fee and Mattmark. Arrows represent stretching lineation direction and dip. Fold axes (parallel to stretching lineation) from Klein [1978] are represented by dashed arrows. Insert shows principal structural units (G St.B, Grand St. Bernard nappe; Fz, Furg zone; Gz, Gornergrat zone). Boxed area refers to figure 6 . 


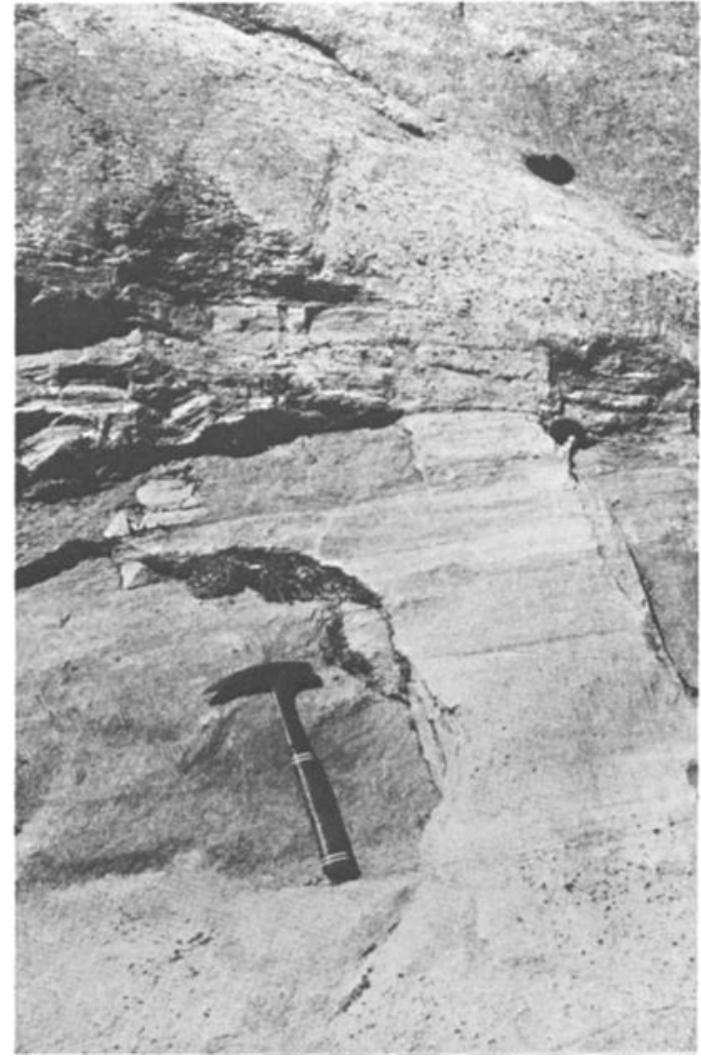

Fig. 8a.

Fig. 8. Deformation characters in granites and orthogneisses. (a) mylonitic band cutting isotropic granite; (b) small scale shear zone; (c) and (d) shear criteria in orthogneisses, South of Mattmark and near Saas Fee, respectively. ultramylonite layers, it must be emphasized that lineation directions and shear senses remain the same in all deformation facies.

\section{THE DEFORMATION IN SEDIMENTARY ROCKS (GORNERGRAT ZONE)}

Microstructures of strongly deformed Mesozoic sedimentary rocks have been studied (1) in the upper Zermatt valley at Gornergrat where metamorphic sediments and paragneisses form a pile of thin thrust slices and (2) near Mattmark where folding is important [Lacassin and Mattauer, 1985].

\section{Microstructures and Deformation} Mechanisms and Regime

Microstructures in samples of quartzphengite schists, quartzites and conglomerates (Triassic), and garnet micaschists (schistes lustrés) from Gornergrat [Lacassin, 1983b] are characterized by polycrystalline quartz riobons with typical characters of plastic deiormation such as small grains (20 to $50 \mu \mathrm{m})$ with sutured boundaries and undulose extinction. In quartzites and conglomerates, elongated quartz grains obilique to the foliation $\left(\approx 25^{\circ}\right)$ and subgrain boundaries making a steeper angle with that foliation $\left(\approx 70^{\circ}\right)$ indicate westward shearing. Quartz $c$ axis fabrics (Figure 12) show well-defined asymmetric girdles with a strong maximum close to $\mathrm{Z}$ characteristic of basal slip, hence low temperature conditions $\left(350^{\circ} \mathrm{C}\right)$.

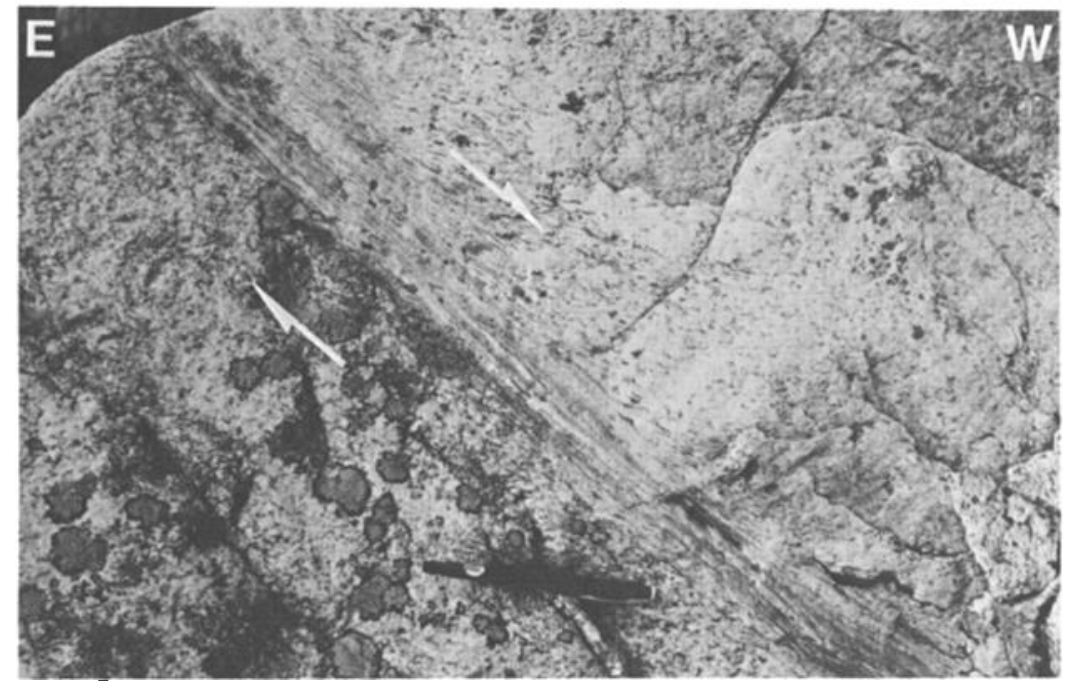

Fig. 8b. 


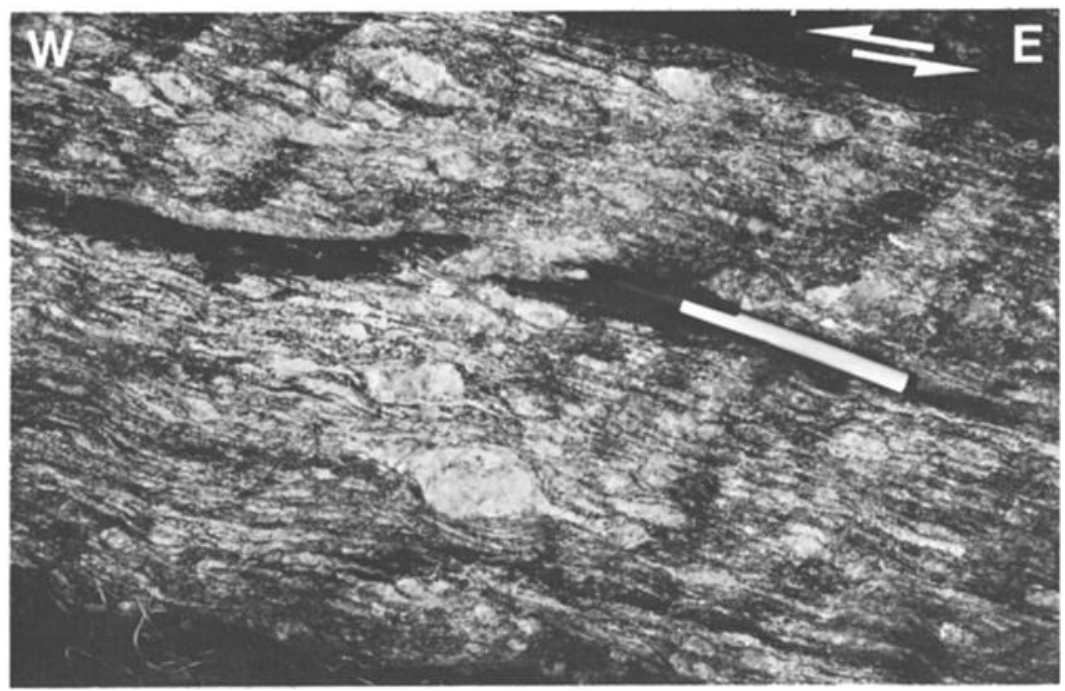

Fig. 8c.

Small (50 $\mu \mathrm{m})$ recrystallized and often deformed phengites have been dated ( ${ }^{39} \mathrm{Ar}$ $40 \mathrm{Ar}$ ) at $37.3 \mathrm{Ma}$ [Chopin and Monié, 1984]. In calcschists and micaschists, often

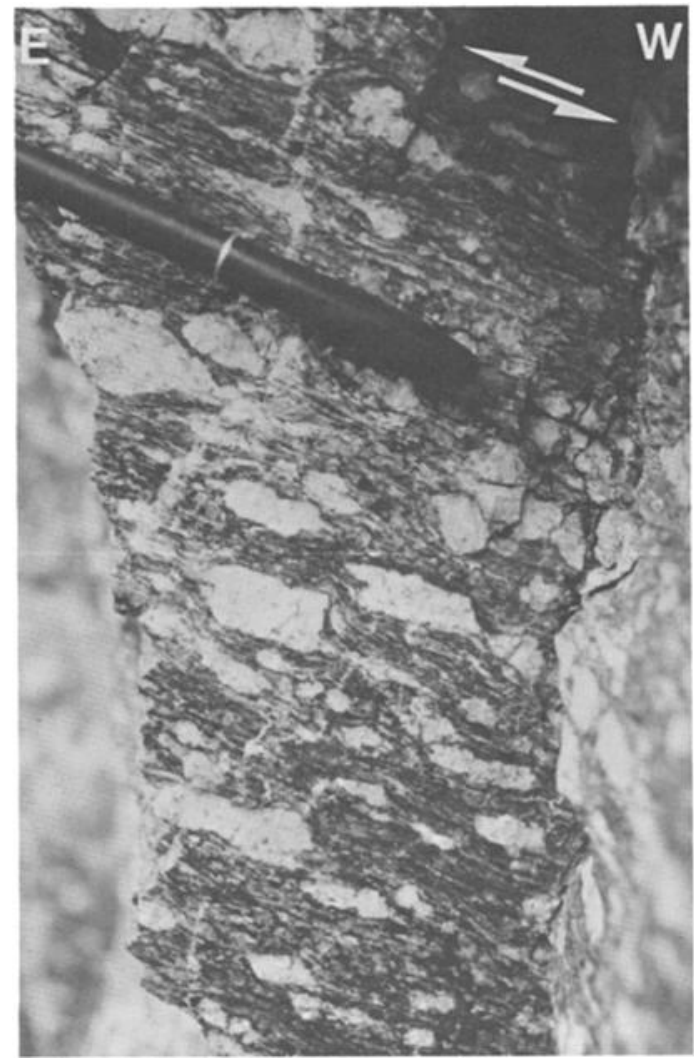

Fig. 8d. fractured garnets also show asymmetric pressure shadows with quartz and chlorite. Sigmoidal inclusions in some of them imply that they are syntectonic.

Most of the micaschists, calcschists and conglomerates are typical plano-linear tectonites with a generally strong elongation of ribbons, pebbles, or pressure shadows. In conglomerates, for instance, quartz pebbles (Figure 5b) show $\mathrm{XZ}$ ratios between 10 and 80 (Figure 13 ) with a $K$ shape ratio close to 1 $(0.5 \leq K \leq 1)$. This suggests that finite strain was close to plane strain. While generally planar fabrics are observed in the quartzites, the linear element being expressed only by alignment of mica plates, intense stretching of the marbles is marked by a prominent boudinage of dolomitic layers (Figures $5 c$ and $5 d$ ).

In XZ planes, quartz microstructures and $c$ axis fabrics (Figure 12), asymmetric pressure shadow crystallizations and boudin rotation in marbles (Figure $5 \mathrm{~d}$ ) imply a clear noncoaxial deformation regime and intense westward shearing in the Gornergrat zone [Lacassin, 1983b].

\section{Fold Geometry}

Deformation in sedimentary cover rocks is characterized by spectacular, metric, highly isoclinal folds with very elongated or stretched limbs (Figure 14a) and generally straight axes parallel to the lineation. Apparent vergences are often toward the WSW, but folds with opposite verugence or "mushroom-shaped" folds are 


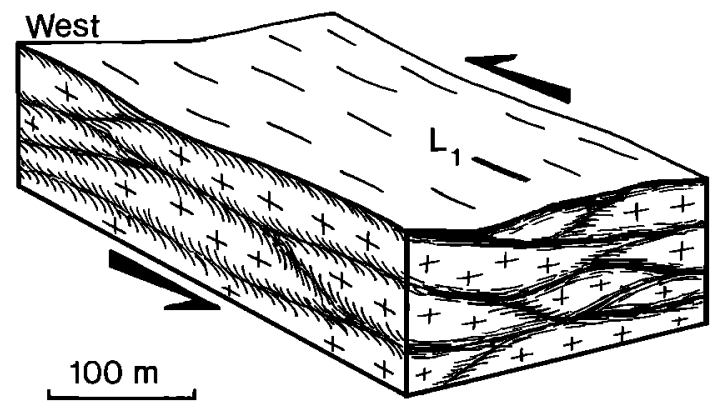

Fig. 9. Shear zone geometry in granites near Mattmark ( $b$, Figure 3), after Lacassin [1983a].

relatively common on the same outcrop. Rare decimetric to metric sheath folds [Quinquis et al., 1978; Cobbold and Quinquis, 1980] and eye structures (sheath fold sections) are also found. Locally, superposition of two generations of folds is attested by the presence of two intersecting foliations in hinge zones [Klein, 1978]. Finally, late minor folds of a different style (chevrons, kinks) overprint the ductile deformation.

At a more regional scale, several large fold structures have been observed and mapped (Figure 14b and 15) Darticularly in the Mattmark area [Güller, 1947; Bearth, 1957]. A spectacular eye structure of kilometric scale, whose geomerry was analyzed by Mattauer [1981] and Lacassin and Mattauer [1985], appears to be a section across a kilometric sheath fold, highly elongated parallel to the lineation. Other hectometric to kilometric isoclinal folds have axes parallel to the stretching lineation (e.g., Figure 15).

\section{P/T CONDITIONS, TIMING OF THE DEFORMATION}

Concurrently with the structural work presented here, a radiochronological study of metamorphic evolution was carried out by $\mathrm{P}$. Monié $[1984,1985]$, using the ${ }^{39} \mathrm{Ar}$ ${ }^{40} \mathrm{Ar}$ technique on phengites and biotites, and petrographic and microprobe analyses. The tectonometamorphic history may be summarized as follows:

In the Southern Monte Rosa nappe (upper Val d'Ayas), eclogitic early alpine crystallizations $\left(16 \mathrm{kbar}, 500^{\circ} \mathrm{C}\right.$ ) are dated at $110 \mathrm{Ma}$ [Chopin and Monié, 1984]. In the Northern Monte Rosa nappe, eclogites are found in the Furg zone [Wetze1, 1972] as boudins of isotropic, retromorphosed rock, embedded in micaschists and gneiss. However, primary deformations associated with the eclogitic metamorphism are never observed.

Blueschist metamorphism (7-8 kbar, $450^{\circ} \mathrm{C}$ ) is widely described [Ernst and Dal Piaz, 1978; Frey et al., 1976]. This event may correspond in the Monte Rosa nappe to the 70- to 60-Ma ages obtained on biotite from sheared granites in the vicinity of the Monte Rosa Hütte (upper Zermatt valley) and implied by isotope analyses of
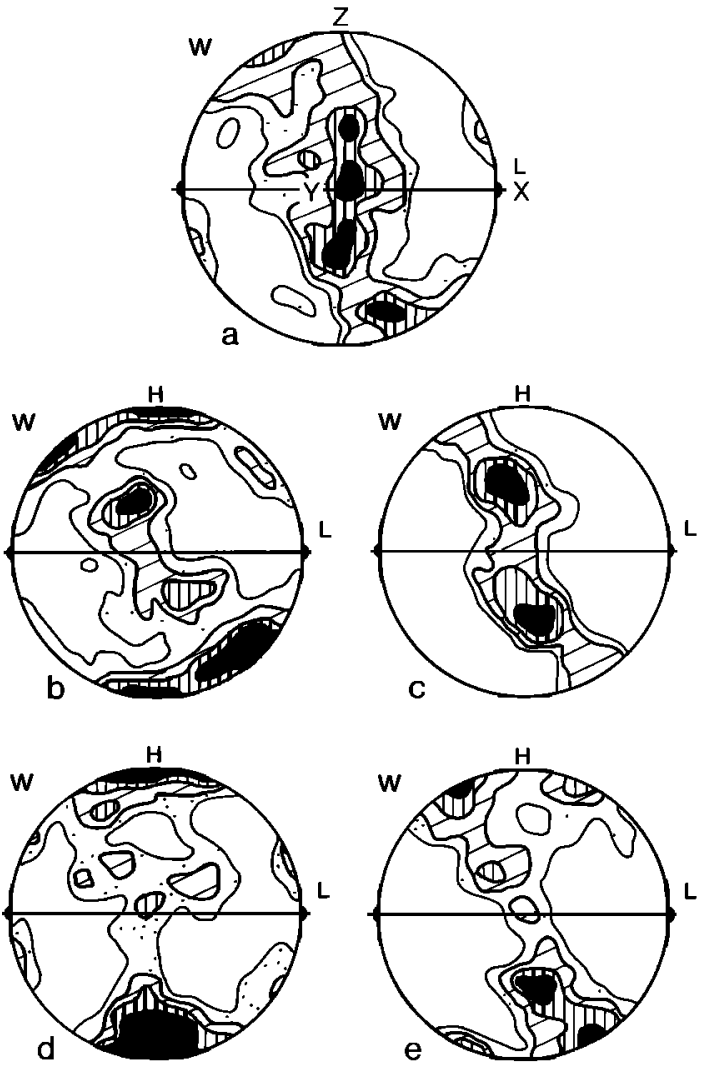

Fig. 10. Quartz c axis fabrics in gneisses and mylonites. (a) central part of shear zone, sample ZA2, W Mattmark shore lake, 340 c axes, contours 1; 1,5; 2,$5 ; 3,5 \%$, maxi $5,5 \%$. (b) orthogneisses, sample SF55, E Mattmark shore lake, $180 \mathrm{c}$ axes, $1 ; 2 ; 3 ; 4 \%$, maxi $5 \%$. (c) mylonite, sample SF62, W Mattmark shore lake, $180 \mathrm{c}$ axes, $1 ; 2 ; 4 ; 8 \%$, maxi $18 \%$. (d) thin ultramylonite crosscutting outer shear zone foliation, sample SF42, MR Hütte, 200 c axes, $1 ; 2 ; 3 ; 4 \%, \operatorname{maxi} 6 \%$. Lower hemisphere Schmidt diagrams (as in Figure 12). Measurements made on Universal stage are presented in XZ plane; $\mathrm{L}$ is lineation and $\mathrm{X}$ axis. 

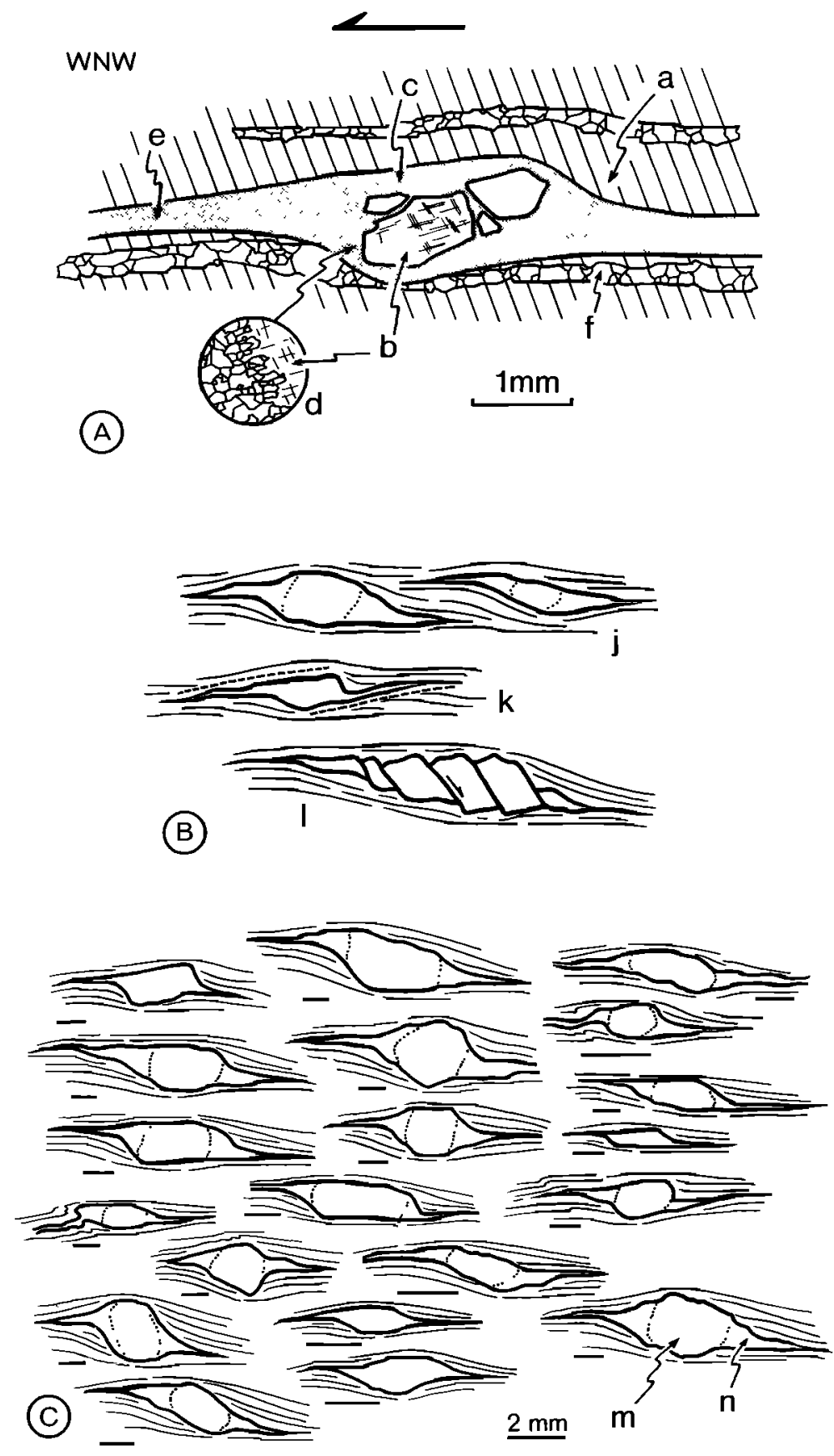

Fig. 11. Characters of feldspar deformation in gneisses (west vergent shear sense). (A) Microstructures: (a) matrix, (b) porphyroclast core, (c) mantle of small recrystallized grains, (d) detail of core mantle boundary, feldspar recrystallized at the core rim, (e) tail resulting from mantle deformation, (f) quartz ribbon. (B) Typical shear criteria: (j) sigmoidal porphyroclast, (k) "tilted" porphyroclast with edges and tails parallel to incipient shear planes (dashed), (1) antithetic slip on fractures within Feldspar. (C) Example of feldspar deformation in shear zone (shear sense determined independently by sigmoidal deflection of macroscopic foliation); (m) porphyroclast core, $(n)$ tail. 

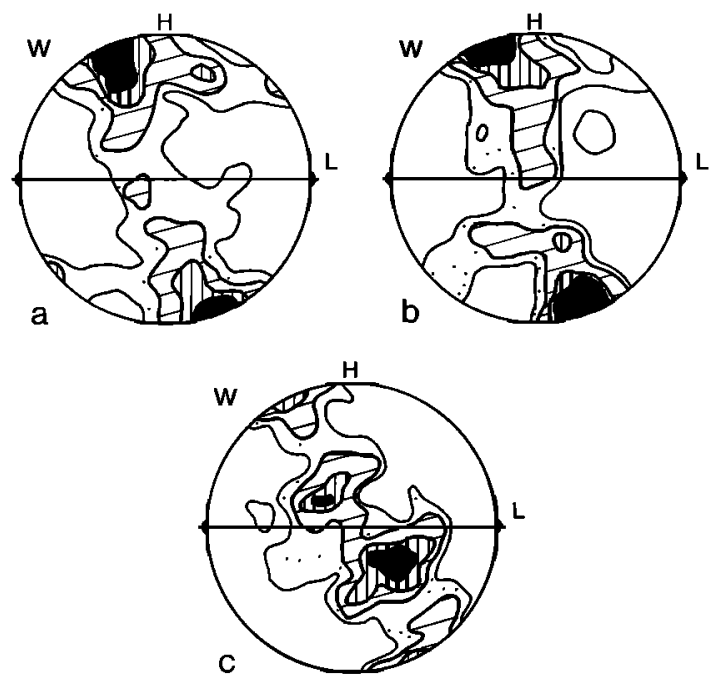

Fig. 12. Quartz $c$ axis fabrics in mesozoic sediments from Gornergrat. All contours : $1 ; 2 ; 4 ; 6 \%$. (a) quartzite, sample SF10, 200 c axes, maxi 9\%. (b) quartz pebble conglomerate, sample SF11, 120 c axes, maxi $12 \%$. (c) garnet micaschist ("schistes lustrés"), sample SF9, 180 c axes, $\operatorname{maxi} 8 \%$.

high-pressure phengites from Gornergrat [Monié, 1984].

Well-defined late Eocene ages (40 Ma) characterize the regional metamorphism under high greenschist conditions [Bearth. 1952; Frey et a1, 1976]. According to Monie [1984], the progressive metamorphic history of gneiss phengites, which exhibit a general age resetting around $40 \mathrm{Ma}$ (37.3 Ma at Gornergrat), implies that the Eocene event could have been a continuation, under progressively lower pressure conditions, of the $60 \mathrm{Ma}$ phase. The most outstanding ductile deformation appears to be broadly synchronous with this regional metamorpinism and may have stopped when rocks reached brittle ductile transition temperatures $\left(\approx 300^{\circ}-350^{\circ} \mathrm{C}\right.$ (Sibson, 1977]). The 40-Ma ages on often deformed biotite and phengite from the Saas Fee gneisses [Monié, 1984, 1985] with ESE-vergent shear criceria imply that ductile backshearing could have occurred during and after the late Eocene, in parts of the Portjengrat unit.

\section{REGIONAL COMPATIBILITY OF OBSERVATIONS}

The sample to outcrop scale strain measurements represented on the detailed and regional maps (Figures 2, 3, 6, and 7) are consistent with a coherent deformation pattern: lineations keep a rather uniform orientation and may be considered as regional markers of shear directions [Escher and Watterson, 1974; Mattauer, 1975; Nicolas and Boudier, 1975]. Shear senses, determined on several samples or outcrops, are reported on Figure 16. The arrows indicate the movement of the hanging wall. Two different units appear to be characterized by opposite shear senses. Movement of hanging-wall units was toward the WNW in the MR nappe and Gornergrat area, but toward the ESE in the Portjengrat unit near Saas Fee.

WNW shear criteria are pervasive in the whole Monte Rosa nappe, including regions outside the present1y studied area [e.g., Cobbold, 1979]. They are consistent with progressive WNW-vergent overthrusting during and after the upper Eocene. So far, however, we have no conclusive evidence to decide whether all the observed strain results from this deformation or whether the deformation was continuous and

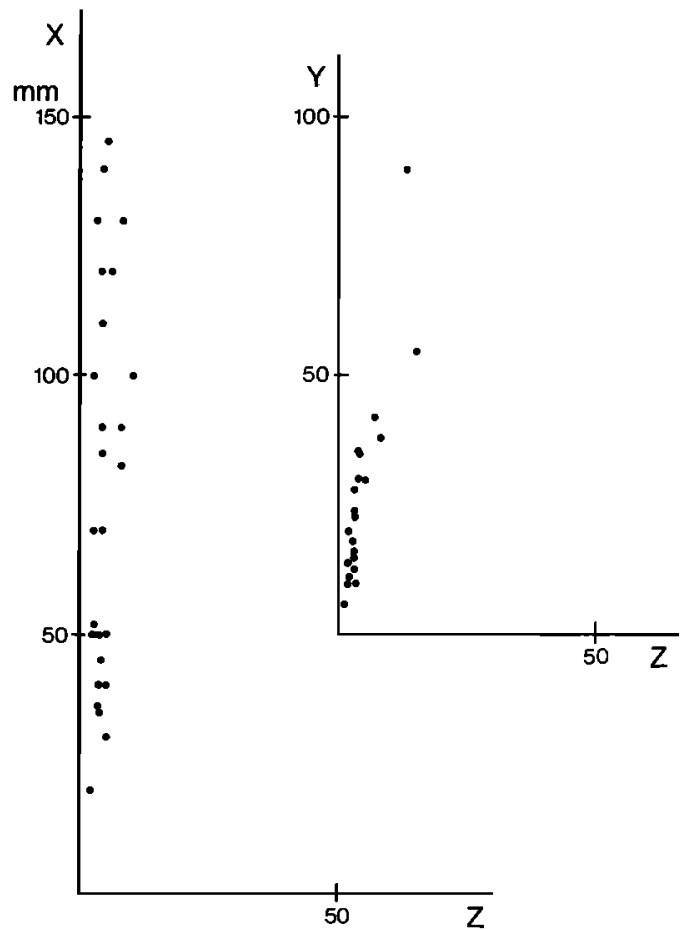

Fig. 13. Pebble shape fabric in conglomerates from Gornergrat. $X \geq Y \geq Z$ are principal axes of elongated pebbles $(10 \leq X / Z \leq 80 ; 0.5 \leq K \leq 1)$. 


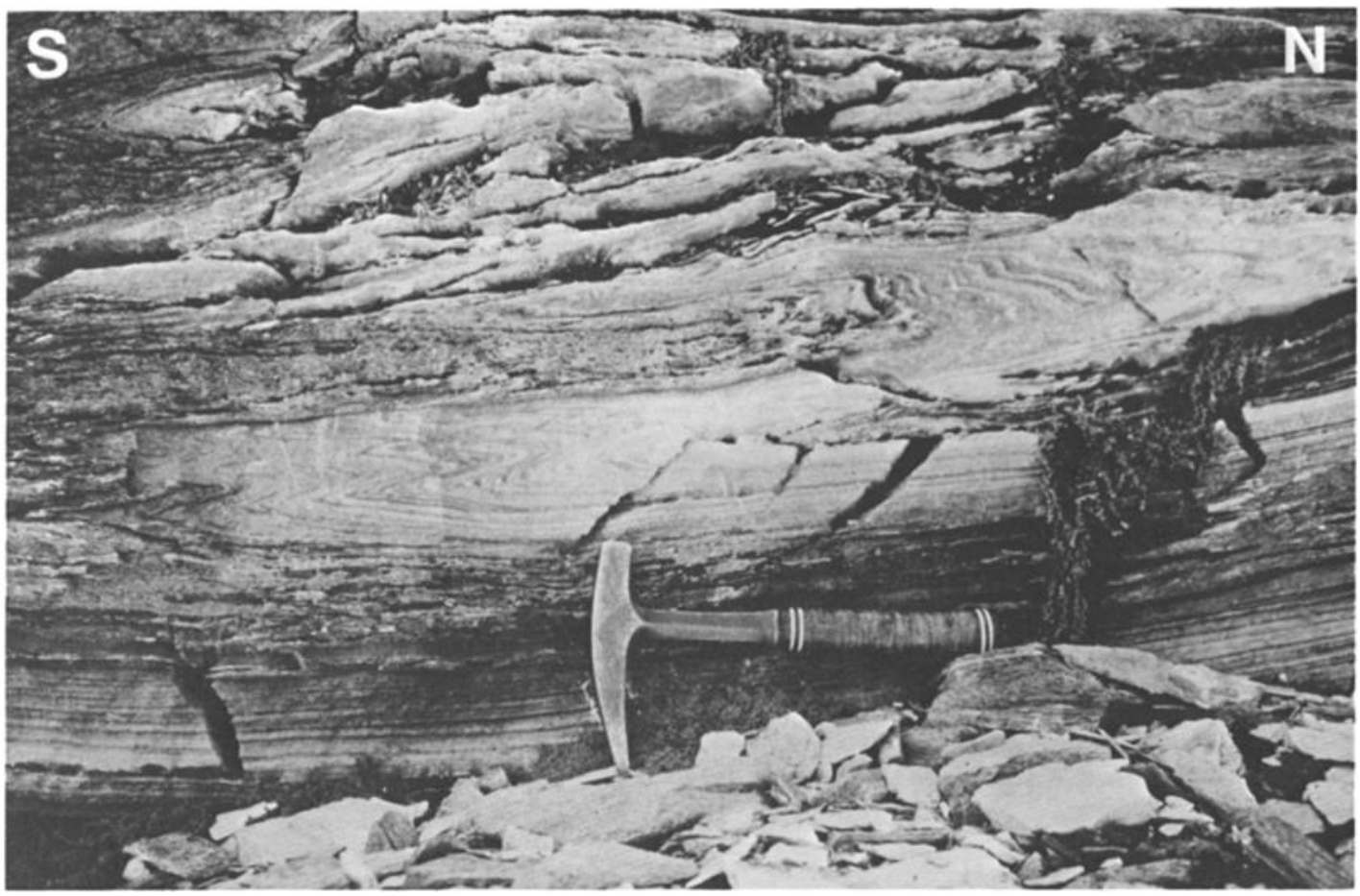

Fig. 14a.

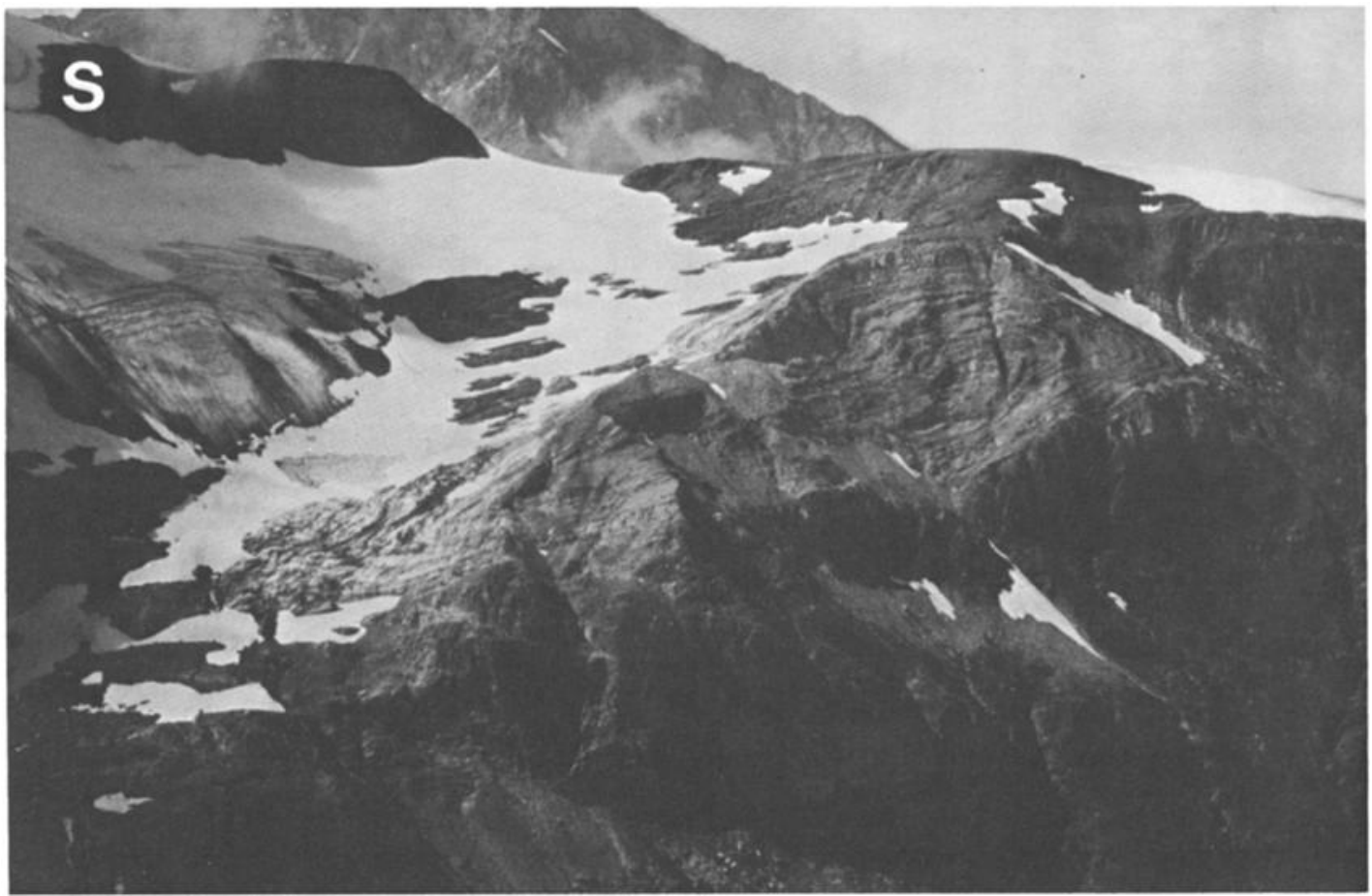

Fig. 14b.

Fig. 14. (a) Isoclinal microfold in marbles (section perpendicular to fold axis and lineation). (b) Mattmark sheath fold [Lacassin and Mattauer, 1985], kilometric eye outlined by marble layers (view to the WNW). 


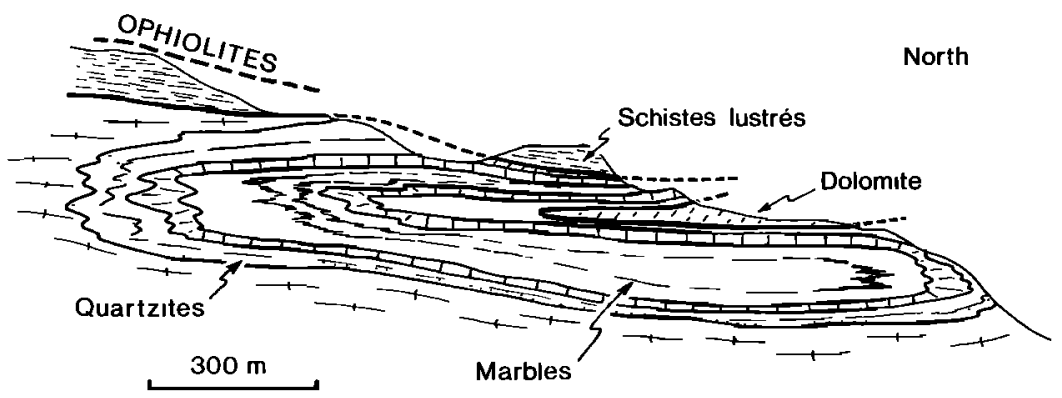

Fig. 15. Kilometer scale refolded isoclinal fold near Mattmark sheath fold in Figure 14b, thrust planes (bold lines) marked by dolomite and cargneule slices; all fold axes are roughly parallel to lineations.

progressive since the high-pressure conditions at 60-70 Ma. Such a large shearing is thought to occur at a crustal scale [Mattauer and Tapponnier, 1978; Malavieille et a1., 1984] with displacements of at least several tens of kilometers [Lacassin and Mattauer, 1985] as in other areas of the Alps and Corsica [e.g., Laurent and Etchecopar, 1976; Mattauer et al., 1977, 1981; Malavieille and Etchecopar, 1981; Chatagnon, 1982; Carpéna and Mailhé, 1984].

The more local "antithetic" shearing toward the ESE in parts of the Portjengrat unit may be considered related to backthrusting in connection with the Mischabel "backfold" [Mïller, 1983]. located immediately above to the north.

These conclusions cannot be reconciled with classical views on folding geometries [Klein, 1978; Milnes et al, 1981] in which fold axes are generally perpendicular to the transport direction and complexities result from superposition of distinct folding phases. As suggested by Lacassin and Mattauer [1985], the folds observed in the Mischabel-Monte Rosa area are better considered as sheath folds or as folds with axes approaching the regional shear direction. Such folds probably form during progressive shearing by kinematic amplification of initial deflections in the attitude of layers [Cobbold and Quinquis, 1980] or by reorientation of folds initially oblique to the transport direction [Escher and Watterson, 1974; Hobbs et al, 1976; Be11, 1978; Berthé and Brun, 1980; Hugon, 1982].

\section{SUMMARY AND DISCUSSION}

Significant, near-simple, ductile shearing in the Monte Rosa area is attested by a coherent regional lineation pattern with average WNW-ESE direction, the compatibility of various shear criteria at different scales of observation in different units, mylonites and shear zones in granites and bulk shearing in gneisses, asymmetric quartz c axis fabrics, and the occurrence of large sheath folds (shear strain close to 20 [Lacassin and Mattauer, 1985]). In the Monte Rosa nappe these different observations are in accordance with crustal overthrusting toward the WNW as a result of continental collision around 40 Ma. Such a deformation mechanism seems to be important in much of the Western Alps, in relation to either obduction or collision [e.g., Malavieille et al., 1984;

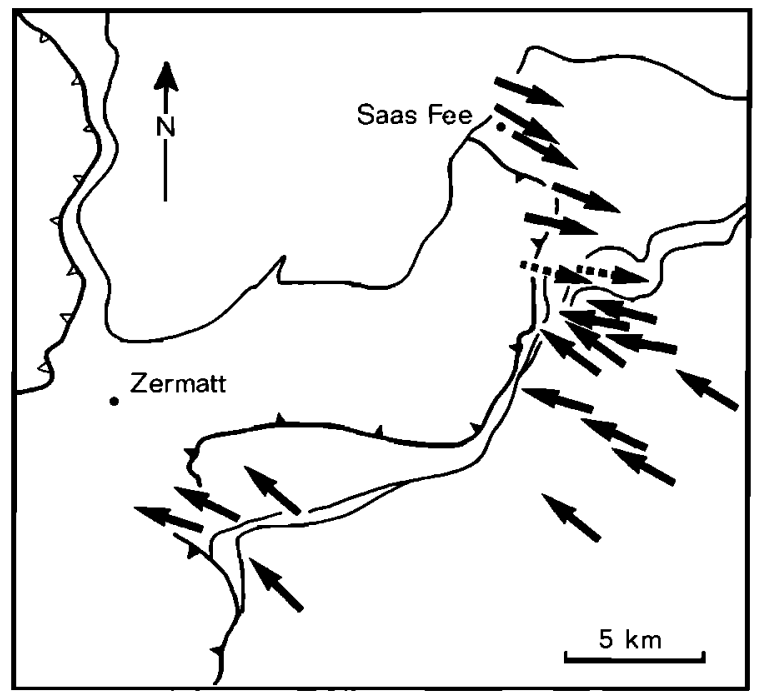

Fig. 16. Shear senses determined from sample and outcrop study at regional scale: arrows represent hangingwall movements; less well constrained shear senses are dashed. 

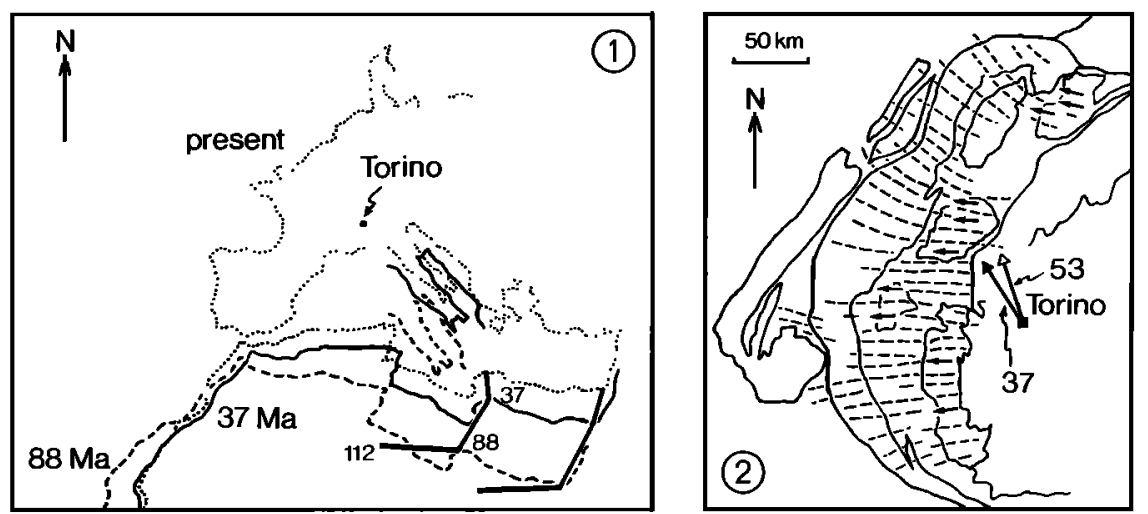

Fig. 17. Comparison between relative displacement of Africa and Europe, and thrusting directions in Western Alps. (1) Positions of Africa and Apulia. Dashed line, $88 \mathrm{Ma}$. Solid line, $37 \mathrm{Ma}$. Dotted line, present. Paths of two points situated on African plate are traced between $112 \mathrm{Ma}$ and present. (2) Major displacement directions (dashed lines and short arrows) on Tertiary overthrusts in Western Alps [Malavieille et al., 1984]. E-W vergent thrusting directions are different from Africa/Eurasia convergence azimuths for period between 53 and $37 \mathrm{Ma}\left(\mathrm{N} 21^{\circ} \mathrm{W}\right.$, open arrow), and at $37 \mathrm{Ma}\left(\mathrm{N} 36^{\circ} \mathrm{W}\right.$, black arrow), for a point situated on the African plate at present location of Torino. On both maps, Apulia is considered part of African plate, movements are in reference frame fixed to present day Europe, and have been calculated using Olivet et al's [1984] reconstructions.

Choukroune et al., 1986]. In the Monte Rosa area it may correspond to the final emplacement of the ophiolite and AustroAlpine (Dent-Blanche) thrust sheets onto the European continental margin (Figures 3 and 4). The displacements absorbed by ductile shearing at the top of the MR nappe have probably reached a minimum of several tens of kilometers [Lacassin and Mattauer, 1985].

At a later stage, more external parts of the European crust, including the external crystalline massifs (Aar, MontBlanc,...), the Gotthard and Tavetsch massifs [Hsii, 1979], the lower Pennine nappes [e.g., Boyer and Elliott, 1982] and their substratum became involved in the underthrusting process, as major thrusts migrated downward and northwestward. A possible ramp flat geometry of a deep, more recent thrust zone [Ménard and Thouvenot, 1984] under the Mischabel-Monte Rosa area could have initiated the backthrusting observed at now shallow levels in the Fortjengrat unit [e.g., Malavieille, 1983].

In contrast with speculations based on limited field evidence le.g., Baird and Dewey, 1986], the $W$ to WNW-vergent movements observed in the Western Alpine arc cannot be reconciled easily with the bulk convergence between Eurasia and
Africa [01ivet et al., 1984; Le Pichon et al., 1986]. Using Olivet et al.'s reconstructions for the period between 53 and $37 \mathrm{Ma}$, and at $37 \mathrm{Ma}$, the azimuths of that convergence are $\mathrm{N} 21^{\circ} \mathrm{W}$ and $\mathrm{N} 36^{\circ} \mathrm{W}$, respectively, for a point situated on the African plate near the present location of the city of Torino, in a reference frame fixed to present-day Europe (Figure 17). Such azimuths are markedly different from the $N 70^{\circ} \mathrm{W}$ average orientation of lineations in the northern part of the arc, in the Monte Rosa. In the Ambin, Gran Paradiso, and Dora Maira massifs the difference is even greater [e.g. Malavieille et al., 1984; Choukroune et al., 1986]. Thus it seems that a compcnenc of westward extrusion of the northwestern tip of Apulia, probably accommodated in part by right-lateral shear on the Insubric line, is required to account for this difference, within the overall regime of NNE to NNW convergence between Africa and Europe in the Tertiary [e.g., Laubscher, 1971; Tapponnier, 1977; Mattauer and Tapponnier, 1978].

Acknowledgments. This work was carried out during a $3^{\text {eme }}$ cycle cursus at the Laboratoire de Géologie Structurale in Montpellier and supported by a DGRST grant, UA 266 of CNRS, and the ATP 
Géodynamique of CNRS-INAG. Particular thanks go to M. Brunel, R. Caby, J. Malavieille, M. Mattauer, and P. Monié for discussions during field trips and for reviewing earlier versions of this paper.

\section{REFERENCES}

Argand, E., Les nappes de recouvrement des Alpes penniques et leurs prolongements structuraux, Beitr. Geol. Karte Schweiz, $31,1-26,1911$.

Baird, A. W., and J. F. Dewey, Structural evolution in thrust belts and relative plate motion: The upper Pennine Piemont zone of the internal Alps, Southwest Switzerland and Northern Italy, Tectonics, 5, 375-387, 1986.

Bearth, P., Geologie und Petrographie des Monte Rosa, Beitr. Geol. Karte Schweiz, N.F.96, 94 pp., 1952.

Bearth, P., Geologisher Atlas der Schweiz, blätter Saas und Monte Moro, Schweiz. Geol. Komm., Kümerly \& Frey, Bern, $195 \%$.

Bearth, P., Die Ophiolite der Zone von Zermatt Saas-Fee, Beitr. Geol. Karte Schweiz, N.F.132, 130 Pp., 1967.

Bearth, P., Zur Gliederung der Bünderschiefer in der Region von Zermatt, Eclogae Geol. Helv., 69, 149161,1976 .

Bell, T. H., Progressive deformation and reorientation of fold axes in a ductile mylonite zone: The Woodroffe Thrust, Tectonophysics, 44, 285-320, 1978.

Berthé, D., and J. P. Brun, Evolution of folds during progressive shear in the South Armorican shear zone, France, J. Struct. Geol., 2, 127-133, 1980 .

Bouchez, J. L,, and A. Pêcher, Plasticité du quartz et sens de cisaillement dans les quartzites du grand chevauchement central himalayen, Bull. Soc. Geol. Fr., $18,1377-1385,1976$.

Boyer, S. E., and D. Elliott, Thrust systems, Am. Assoc. Pet. Geol. Bul1., $66,1196-1230,1982$.

Brunel, M., Quartz fabric in shear zone mylonites: Evidence for a major imprint due to late strain increments, Tectonophysics, 64, T33-T44, 1980.

Burg, J. P. and P. Laurent, Strain analysis of a shear zone in a granodiorite, Tectonophysics, 47, 1-42, 1978 .

Carpéna, J. and D. Mailhé, Plis en fourreau hectométrique au coeur de l'orthogneiss du Grand Paradis (Alpes Occidentales Italiennes), C. R. Seances Acad. Sci. Ser. 2, 298, 41 $\overline{5-4} \overline{18}, 1984$.
Carpenter, M. A., Omphacite microstructures as time-temperature indicators of blue-schist and eclogite facies metamorphism, Contrib. Mineral. Petrol., 78, 441-451, 1981 .

Chatagnon, F., L'analyse d'images appliquée à des problèmes structuraux: (1) fracturation du site du barrage de Vinça (P.O.), (2) structure d'un marbre de Carrare, (3) déformation des quartzites du massif de Dora Maira, Thesis, 125 pp., Univ. of Grenoble, Grenoble, France, 1982.

Chopin, C., and P. Monié, A unique Mgchloritoid-bearing, high-pressure assemblage from the Monte Rosa, Western Alps: a petrologic and $40 \mathrm{Ar} 39 \mathrm{Ar}$ radiometric study, Contrib. Mineral. Petrol., 87, 338-398, 1984 .

Choukroune, P., M. Ballèvre, P. Cobbold, Y. Gautier, O. Merle, and J. P. Vuichard, Deformation and motion in the Western alpine arc, Tectonics, 5, 215226, 1986.

Cobbold, P., Sheath folds and large strains in rocks, J. Struct. Geol., 1 , $338,1979$.

Cobbold, P., and H. Quinquis, Development of sheath folds in shear regimes, J. Struct. Geol., 2, 119-126, 1980.

Frnst, W., Interpretative synthesis of metamorphism in the Alps, Geol. Soc. Am. Bul1., 84, 2053-2078, 1973.

Ernst, W., and G. Dal Piaz, Mineral parageneses of eclogitic rocks and related mafic schists of the Piemonte ophiolite nappe, Breuil St Jacques, Italian Western Alps, Am. Mineral., 63, 621-640, 1978.

Escher, A., and J. Watterson, Stretching fabrics, folds and crustal shortening, Tectonophysics, 22, 223-231, 1974.

Etchecopar, A., Etude des états de contraintes en tectonique cassante et simulation de déformations plastiques (approche mathématique), Thes is Sciences, 296 pp., Univ. of Montpe1lier, Montpellier, France, 1984.

Flinn, D., On the symmetry principle and the deformation ellipsoid, Geol. Mag., $102,36-45,1965$.

Frey, M., J. C. Hunziker, W. Franck, J. Bocquet, G. V. Da1 Piaz, E. Jager and E. Niggli, Alpine metamorphism of the Alps, a review, Schweiz. Mineral. Petrogr. Mitt., 54, 247-291, 1974.

Frey, M., J. C. Hunziker, J. R. O'Neil, and H. W. Schwander, Equilibriumdisequilibrium relations in the Monte Rosa granite, Western Alps: Petrologica1 
$\mathrm{Rb}-\mathrm{Sr}$ and stable isotope data, Contrib. Mineral. Petrol., 55, 147-179, 1976.

Gïller, A., Zur Geologie der südlichen Mischabel und der Monte Rosa Gruppe, Eclogae. Geol. Helv., 40, 41-151, 1947.

Higgins, M. W., Cataclastic rocks, U.S. Geol. Surv. Prof. Pap., 687, 97 pp., 1971 .

Hobbs, B., W. Means, and P. Williams, An outline of structural geology, John Wiley, New York, 1976.

Homewood, P., G. Gosso, A. Escher, and A. G. Milnes, Cretaceous and Tertiary evolution along the Besançon Biella traverse (Western Alps), Eclogae Geol. Helv., 73, 635-649, 1980.

Hsï, K. J., Thin-skinned plate tectonics during neo-alpine orogenesis, Am. J. Sci., 279, 353-366, 1979.

Hugon, H., Structures et déformation du massif de Rocroi (Ardennes). Approche géométrique, quantitative et expérimentale, Thesis, 98 pp., Univ. of Rennes, Rennes, France, 1982.

Hunziker, J. C., Polymetamorphism in the Monte Rosa, W. Alps, Eclogae Geol. Helv., 63, 151-161, 1970 .

Kiénast, J. R., Sur l'existence de deux séries différentes au sein de l'ensemble schistes lustrés ophiolitiques du Val d'Aoste, C. R. Seances Acad. Sci. Ser. D, $276,2 \overline{62} 1-2624,1973$.

$\mathrm{Kle}$ in, J., Post nappe folding southeast of the Mischabel ruickfalte (Pennine Alps) and some aspects of the associated metamorphism, Leidse Geol. Meded., 51, 233-312, 1978 .

Lacassin, R., Cisaillement ductile et déformation hétérogène du granite de la nappe du Mont Rose dans la vallée de Saas (Suisse), C. R. Seances Acad. Sci.

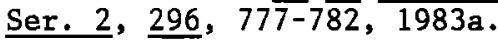

Lacassin, R., Mise en évidence d'une zone de cisaillement ductile majeure dans la couverture de la nappe du Mont Rose: Etude microstructurale, C. R. Seances Acad. Sci. Ser. 2, 297, 613-618, 1983b.

Lacassin, R., Etude des mécanismes de déformation dans le versant Nord de la nappe du Mont Rose (Alpes Suisses) et relation avec les grands chevauchements. Approche méthodologique de $1 \mathrm{a}$ déformation des roches gneissiques, Thesis, 221 pp., Univ. of Montpellier, Montpellier, France, 1984.

Lacassin, R., and M. Mattauer, Kilometre scale sheath fold at Mattmark and implications for transport direction in the Alps, Nature, 316, 739-742, 1985. Laduron, D., L'antiforme de Vanzone; étude pétrologique et structurale dans la vallée Anzasca (province de Novara, Italie), Mém. Inst. Geol. Univ. Louvain, $28,1-121,197 \overline{6}$.

Lagarde, J. L., La déformation des roches dans les domaines à schistosité subhorizontale, Thesis, 164 pp., Univ. of Rennes, Rennes, France, 1978.

Laubscher, H. P., The plate scale kinematics of the Western Alps and the northern Apennines and its palinspatic implications, Am. J. Sci., 271, 193-226, 1971.

Laurent, P., and A. Etchecopar, Mise en évidence à 1 'aide de la fabrique du quartz d'un cisaillement simple à déversement Ouest dans le massif de Dora Maira, Bul1. Soc. Geol. Fr., 18, 1387$1393,1976$.

Le Pichon, X., F. Bergerat, and M. J. Roulet, Plate kinematics and Tectonics leading to the Alpine belt formation: a new analysis, Geol. Soc. Am. Bul1., in press, 1986.

Malavieille, J., Modélisation expérimentale des chevauchements imbriqués: application aux chaines de montagne, Bul1. Soc. Geol. Fr., 26, 129$138,1983$.

Malavieille, J., and A. Etchecopar, Ductile shear deformation of quartzite in an Alpine crustal thrust (Ambin massif), Tectonophysics, 78, 65-71, 1981.

Malavieille, J., A. Etchecopar, and J. P. Burg, Analyse de la géométrie des zones abritées: simulation et application à des exemples naturels, C. R. Seances Acad. Sci. Ser. 2, 294, $77 \overline{9-7} \overline{84,1982 .}$

Malavieille, J., R. Lacassin, and M. Mattauer, Signification tectonique des linéations d'allongement dans les Alpes occidentales, Bull. Soc. Geol. Fr., 26, 895-906, 1984.

Mattauer, M., Sur le mécanisme de formation de la schistosité dans 1'Himalaya, Earth Planet. Sci. Lett., $\underline{28}, 144-154, \underline{1975}$.

Mattauer, M., Plis en fourreau d'échelie plurikilométrique dans la zone interne des Alpes suisses (couverture Nord de la nappe du Mont Rose), C. R. Seances Acad. Sci. Ser. D, 293, 929-932, 1981 .

Mattauer, M., and P. Tapponnier, Tectonique des plaques et tectonique intracontinentale dans les Alpes FrancoItaliennes, C. R. Seances Acad. Sci. Ser. D, 287, 899-902, 1978 .

Mattauer, M., F. Proust, and A. Etchecopar, Linéation a et mécanisme de 
cisaillement simple lié au chevauchement de la nappe des schistes lustrés en Corse, Bull. Soc. Geol. Fr., 19, 841847,1977 .

Mattauer, M., M. Faure, and J. Malavieille, Transverse lineation and large-scale structures related to Alpine obduction in Corsica, J. Struct. Geol., 3, 401-409, 1981 .

Mattauer, M., B. Collot, and J. Van Den Driessche, Alpine model for the internal metamorphic zones of the North American Cordillera, Geology, 11, 11-15, 1983.

Ménard, G., and F. Thouvenot, Ecaillage de la lithosphère européenne sous les Alpes occidentales: Arguments gravimétriques et sismiques liés à 1 'anomalie d'Ivrea, Bul1. Soc. Geol. Fr., 26, 875-884, 1984.

Milnes, A. G., M. Greller, and R. Muller, Sequence and style of major post-nappe structures, Simplon-Pennine Alps, J. Struct. Geol., 3, 411-420, 1981 .

Monié, P., Etude par la méthode 39Ar 40Ar de la redistribution de l'Argon dans les minéraux des socles anciens repris par 1 'orogénèse alpine. Application à la géochronologie des massifs de 1 'Argentera-Mercantour, du Mont Rose et de la Grande-Kabylie, Thesis, 206 pp., Univ. of Montpellier, Montpellier, France, 1984.

Monié, P., La méthode 39Ar 40Ar appliquée au métamorphisme alpin dans le massif $\mathrm{du}$ Mont Rose (Alpes occidentales). Chronologie détaillée depuis $110 \mathrm{Ma}$, Eclogae. Geo1. Helv., 78, 487-516, 1985.

Müller, R., Die tektonische Erfoschung des Penninischen Alpen, Eclogae Geol. Helv., 75, 447-479, 1982 .

Muiller, R., Die Struktur der Mischabel falte (Penninische Alpen), Eclogae Geol. Helv., 76, 391-416, 1983.

Nicolas, $\overline{A .}$, and F. Boudier, Kinematic interpretation of folds in alpine-type peridotites, Tectonophysics, 25, 233$260,1975$.

Nicolas, A., and J. P. Poirier, Crystalline plasticity and solid state flow in metamorphic rocks, $444 \mathrm{pp}$., Wiley-Interscience, New York, 1976.

Oberhänsli, R., P. T. Bestimmungen anhand von Mineralanalysen in Eklogiten un Glaucophaniten der Ophiolite von Zermatt, Schweiz. Mineral. Petrogr. Mitt., 60, 215-235, 1980.

olivet, J.L., J. Bonnin, P. Beuzart, and J. M. Auzende, Cinématique de 1 'Atlantique Nord et central, Publ. CNEXO, 54, Centre National pour 1'Exploitation des Océans, Paris, 108 pP., 1984.
Quinquis, H., C. Audren, J. P. Brun, and P. Cobbold, Intense progressive shear in the Ile de Groix blue-schists and compatibility with subduction or obduction, Nature, 273, 43-45, 1978.

Ramsay, J. G., Shear zone geometry: A review, J. Struct. Geol., 2, 83-99, 1980.

Ramsay, J. G., and R. Graham, Strain variation in shear belts, Can. J. Earth Sci., 7, 786-812, 1970.

Reinhardt, B., Geologie und Petrographie der Monte Rosa Zone, der Sesia Zone und des Canavese in gebiet zwischen Valle d'ossola und Valle Loana, Schweiz. Mineral. Petrogr. Mitt., 46, 553-678, 1966.

Schmid, S. M., Microfabric studies as indicators of deformation mechanisms and flow laws operative in mountain building, in Mountain Building Processes, edited by K. J. Hsü, Academic, pp. 95-110, Orlando, Fla., 1983.

Sibson, R., Fault rocks and fault mechanisms, J. Geo1. Soc. London, 133, $191-213,197 \overline{7}$.

Simpson, C., and S. M. Schmid, An evaluation of criteria to deduce the sense of movement in sheared rocks, Geol. Soc. Am. Bul1., 94, 1281-1288, 1983.

Steck, A., Structures de déformation tertiaire dans les Alpes centrales, Eclogae Geol. Helv., 77, 55-100, 1984.

Tapponnier, P., Evolution tectonique du système alpin en Méditerranée: Poinçonnement et écrasement rigide plastique, Bull. Soc. Geol. Fr., 19, 437-460, 1977.

Wetzel, R., Zur Petrographie und Mineralogie der Furgg-Zone (Monte Rosa Decke), Schweiz. Mineral. Petrogr. Mitt., 55, 161-236, 1972 .

White, S., The effect of strain on the microstructures, fabrics and deformation mechanisms in quartzites, Phil. Trans. R. Soc. London Ser. A, 283, 69-86, 1976.

R. Lacassin, Laboratoire de Tectonique, Mécanique de la Lithosphère, U.A. 1093 Centre National de 1a Recherche Scientifique, Institut de Physique du Globe de Paris, 4 P1. Jussieu, 75252 Paris Cédex 05, France.

(Received January 31, 1986; revised August 15, 1986; accepted August 22, 1986.) 